\title{
Temperature, light, and photoperiod responses of some Northeast American and West European endemic rhodophytes in relation to their geographic distribution*
}

\author{
C. Yarish ${ }^{1,2}$, A. M. Breeman ${ }^{1}$ \& C. van den Hoek ${ }^{1}$ \\ ${ }^{1}$ Department of Marine Biology, Biological Centre; P.O.Box 14, NL-9750 AA Haren (Gn), \\ The Netherlands \\ ${ }^{2}$ University of Connecticut, Biological Sciences Group; Stamford, CT 06903, USA*
}

ABSTRACT: The relationship between distributional boundaries and temperature responses of some Northeast American and West European endemic and amphiatlantic rhodophytes was experimentally determined under varying regimes of temperature, light, and daylength. Potentially critical temperatures, derived from open ocean surface summer and winter isotherms, were inferred from distributional data for each of these algae. On the basis of the distributional data the algae fall within the limits of three phytogeographic groups: (1) the Northeast American tropical-to-temperate group; (2) the warm-temperate Mediterranean Atlantic group; and (3) the amphiatlantic tropical-to-warm temperate group. Experimental evidence suggests that the species belonging to the northeast American tropical-to-temperate group (Grinnellia americana, Lomentaria baileyana, and Agardhiella subulata) have their northern boundaries determined by a minimum summer temperature high enough for sufficient growth and/or reproduction. The possible restriction of 2 species ( $G$. americana and $L$. baileyana) to the tropical margins may be caused by summer lethal temperatures (between 30 and $35^{\circ} \mathrm{C}$ ) or because the gradual disintegration of the upright thalli at high temperatures $\left(>30^{\circ} \mathrm{C}\right)$ promotes an ephemeral existence of these algae towards their southern boundaries. Each of the species have a rapid growth and reproductive potential between $15-30{ }^{\circ} \mathrm{C}$ with a broad optimum between $20-30^{\circ} \mathrm{C}$. The lower limit of survival of each species was at least $0{ }^{\circ} \mathrm{C}$ (tested in short days only). Growth and reproduction data imply that the restrictive distribution of these algae to the Americas may be due to the fact that for adequate growth and/or reproduction water temperatures must exceed $20^{\circ} \mathrm{C}$. At temperatures $\leqq 15^{\circ} \mathrm{C}$ reproduction and growth are limited, and the amphiatlantic distribution through Iceland would not be permitted. On the basis of experimental evidence, the species belonging to the warm-temperate Mediterranean Atlantic group (Halurus equisetifolius), Callophyllis laciniata, and Hypoglossum woodwardii), have their northern boundaries determined by winter lethal temperatures. Growth of $H$. equisetifolius proceeded from $10-25^{\circ} \mathrm{C}$, that of $C$. laciniata and $H$. woodwardii from $5-25^{\circ} \mathrm{C}$, in each case with a narrow range for optimal growth at ca. $15^{\circ} \mathrm{C}$. Tetrasporelings of $H$. woodwardii showed limited survival at $0{ }^{\circ} \mathrm{C}$ for up to $4 \mathrm{~d}$. For all members of the group tetrasporangia occurred from $10-20^{\circ} \mathrm{C}$. The southern boundary of $H$. equisetifolius and $C$. laciniata is a summer lethal temperature whereas that of $H$. woodwardii possibly is a winter growth and reproduction limit. Since each member of this group has a rather narrow growth and survival potential at temperatures $<5^{\circ} \mathrm{C}$ and $>20^{\circ} \mathrm{C}$, their

\footnotetext{
- Paper presented at the Seaweed Biogeography Workshop of the International Working Group on Seaweed Biogeography, held from 3-7 April, 1984 at the Department of Marine Biology, University of Groningen (The Netherlands). Convenor: C. van den Hoek.

* Present address.
} 
occurrence in northeast America is unlikely. The (irregular) distribution of Solieria tenera (amphiatlantic tropical-to-warm temperate) cannot be entirely explained by the experimental data (possibly as a result of taxonomic uncertainties).

\section{INTRODUCTION}

The geographic distributions of benthic marine algae have been most often correlated with temperature regimes of the surface waters (Setchell, 1915, 1920; van den Hoek, 1975, 1982a, b). Edwards and Kapraun have demonstrated through combination of phenologicial observations (Edwards \& Kapraun, 1973; Kapraun \& Zechman, 1982) and responses to environmental parameters in laboratory culture (Edwards, 1969, 1970, 1979; Yarish \& Edwards, 1982; Kapraun, 1977a, b, 1978, 1979) that conclusions can be drawn about biogeographic affinities of certain taxa, and possibly of an entire flora (Kapraun, 1980). Therefore, the best evidence for illustrating biogeographic relationships is the design of hypotheses which can be experimentally tested.

Van den Hoek (1982b) has pointed out that in many species where life history studies have been reported, lethal temperatures are rarely investigated. Several studies which have reported on the survival limits of benthic marine algae have failed to use any consistent exposure time, i.e. Biebl $(1958,1962)$ used $12 \mathrm{~h}$, Lüning (1984) used $7 \mathrm{~d}$ and Bolton (1983) utilized $21 \mathrm{~d}$. Exposure times as long as $42 \mathrm{~d}$ and $60 \mathrm{~d}$ are reported by McLachlan \& Bird (1984) and Cambridge et al. (1984), respectively. These longer periods of exposure for temperature tolerance experiments may give clearer estimations of a mature plant's survival potential during long adverse periods. Even the question of the differences in the temperature tolerance of juvenile plants, or the appropriate combinations of factors for reproduction of the mature plants, has not been adequately addressed for phytogeographic boundaries (Dring, 1982).

The present study was designed to answer several phytogeographic questions. Do species with isomorphic alternation of generations have similar temperature responses in each phase? Do juvenile plants have similar temperature tolerances to mature ones? Is it possible by knowing winter and summer mean surface water isotherms coinciding with geographic boundaries to infer the limiting temperature for growth and/or survival of a species? Finally, do benthic marine red algae in van den Hoek's phytogeographic groupings $(1982 \mathrm{a}, \mathrm{b})$ have similar growth or survival strategies?

Phytogeographic hypotheses of temperature boundaries for benthic marine red algae based on ocean isotherms

On the basis of distribution data the investigated algae fall within the limits of the following phytogeographic groups (van den Hoek, 1982a, b):

The Northeast American tropical-to-temperate group (Grinnellia americana, Lomentaria baileyana, Agardhiella subulata); the amphiatlantic tropical-to-warm temperate group (Solieria tenera) and the warm temperate Mediterranean Atlantic group (Halurus equisetifolius, Callophyllis laciniata, Hypoglossum woodwardii). For each species hypotheses will be presented as to the ocean isotherms at the northern (poleward) and southern (equatorward) boundaries (or at the equator) which might delimit the geographic distribution. 
The Northeast American tropical-to-temperate group

\section{Grinnellia americana}

On the basis of distribution data (Fig. 1) one would expect the northern boundary to be either a growth and/or reproduction one at the $17{ }^{\circ} \mathrm{C}$ August (summer) isotherm, or a lethal one at the $0^{\circ} \mathrm{C}$ February (winter) isotherm. The former corresponds with a minimum temperature of at least $15^{\circ} \mathrm{C}$ needed for growth and reproduction in summer (van den Hoek, 1982a, b). The latter corresponds with a minimum temperature of $-1.8^{\circ} \mathrm{C}$ (minimum temperature of unfrozen seawater) for survival in winter (van den Hoek, $1982 \mathrm{a}, \mathrm{b})$. The southern boundary may be either on the $26^{\circ} \mathrm{C}$ August (summer) isotherm (which corresponds to a southern lethal boundary temperature of at least $29^{\circ} \mathrm{C}$ according to van den Hoek $\left(1982 \mathrm{a}_{i}\right.$ b), or on the $25^{\circ} \mathrm{C}$ February (winter) isotherm (which corresponds to a southern growth and/or reproduction boundary of at most $27^{\circ} \mathrm{C}$ ). If the

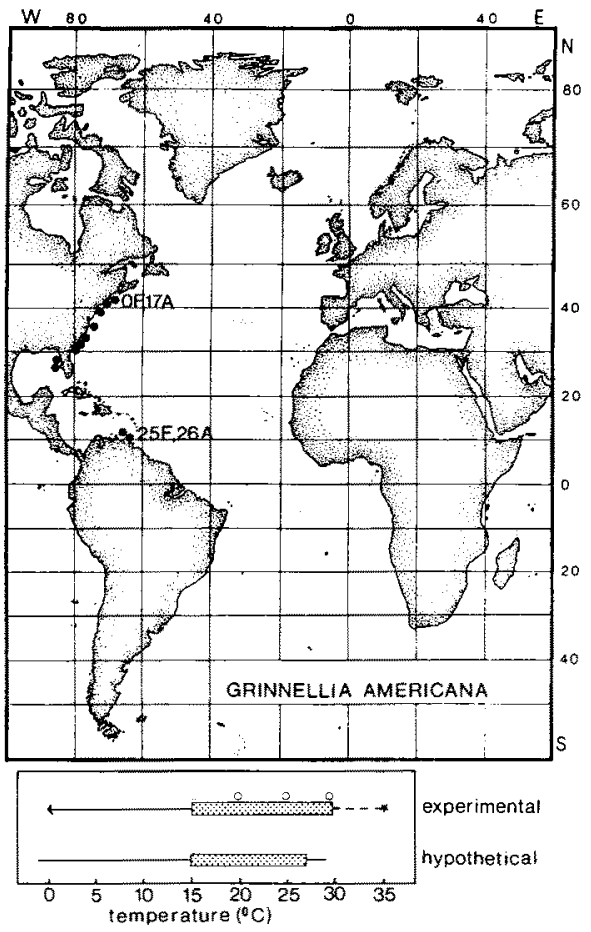

Fig. 1. The distribution of Grinnellia americana. Map shows the geographic distribution and gives the ocean isotherms for February (F) und August (A). Bar diagram compares hypothetically derived temperature ranges for growth and survival from ocean isotherms for winter and summer at northern and southern boundaries, respectively, with experimentally determined limits. Experimental points at $5^{\circ} \mathrm{C}$ intervals as indicated on temperature axis. The symbols in bar diagrams are defined as: (-) survival in the interval; $(--)$ death occurs in the interval; $\left({ }^{\circ}\right)$ lethal temperature

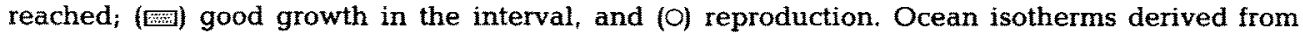
Sverdrup et al. (1942). Distribution data on $G$. americana from the following sources: Brauner (1975), Chapman (1971), Coleman \& Mathieson (1974), Dawes (1974), Earle (1968), Humm (1979), Orris \& Taylor (1973), Rhodes (1970), Schneider et al. (1979), Searles \& Schneider (1978), Sears \& Wilce (1975), Taylor (1957, 1960), Yarish \& Edwards (unpubl. obs.) 
two records from the north coast of Venezuela are excluded, the distribution data suggest that the species either cannot survive temperatures higher than $30^{\circ} \mathrm{C}$ (which are surpassed in lagoons where the species grows) or needs lowered temperatures (e.g. $<22{ }^{\circ} \mathrm{C}$, corresponding with the $20^{\circ} \mathrm{C}$ February isotherm) once a year to complete its life history.

\section{Lomentaria baileyana}

On the basis of distribution data (Fig. 2) one would expect the northern boundary to be either a $15^{\circ} \mathrm{C}$ August isotherm (corresponding with a minimum temperature of $13^{\circ} \mathrm{C}$ for growth and reproduction) or a $-1{ }^{\circ} \mathrm{C}$ February isotherm (corresponding with a

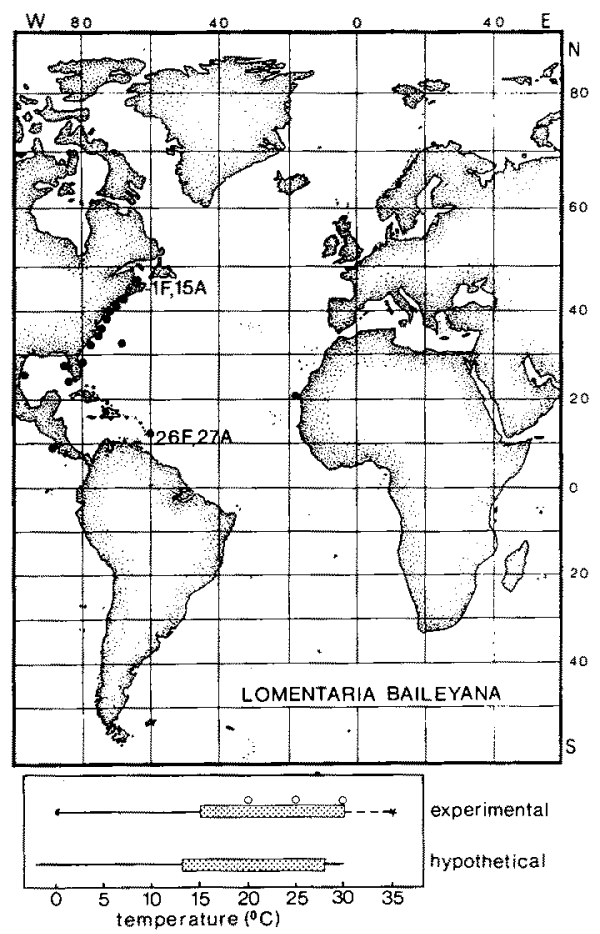

Fig. 2. The distribution of Lomentaria baileyana. Map shows the geographic distribution and gives the ocean isotherms at the northern and southern boundaries. Note hypothetically derived and experimentally determined temperature ranges for growth, reproduction and survival. For rest of legend see Fig. 1. Distribution data on L. baileyana from the following sources: Brauner (1975), Chapman (1971), Coleman \& Mathieson (1974), Dawes (1974), Earle (1968), Edelstein et al. (1967), Edwards \& Kapraun (1973), Humm (1964, 1979), Kapraun \& Zechman (1982), Mathieson (1979), Mathieson \& Dawes (1975), Orris \& Taylor (1973), Schneider et al. (1979), Searles \& Schneider (1978), Sears \& Wilce (1975), Seoane-Camba (1960), Taylor $(1957,1960)$

minimum winter lethal temperature of $-1.8^{\circ} \mathrm{C}$ ). The southern boundary may be either on the $27^{\circ} \mathrm{C}$ August isotherm (which corresponds to a southern lethal boundary temperature of at least $30^{\circ} \mathrm{C}$ ) or the $26^{\circ} \mathrm{C}$ February isotherm (which corresponds to a southern growth and reproduction boundary of at most $28^{\circ} \mathrm{C}$ ). If the record from Barbados is 
excluded, the distribution data suggest that the species cannot survive temperatures higher than $30^{\circ} \mathrm{C}$ (which are surpassed in lagoons where the species grows), or needs lowered temperatures (e.g. $22^{\circ} \mathrm{C}$, corresponding with the $20^{\circ} \mathrm{C}$ February isotherm) once a year to complete its life history.

\section{Agardhiella subulata}

The distribution data (Fig. 3) along the East American coast suggest the northern boundary to be either a growth and/or reproduction one at the $15^{\circ} \mathrm{C}$ August isotherm (corresponding with a minimum summer temperature of $13^{\circ} \mathrm{C}$ for growth and reproduc-

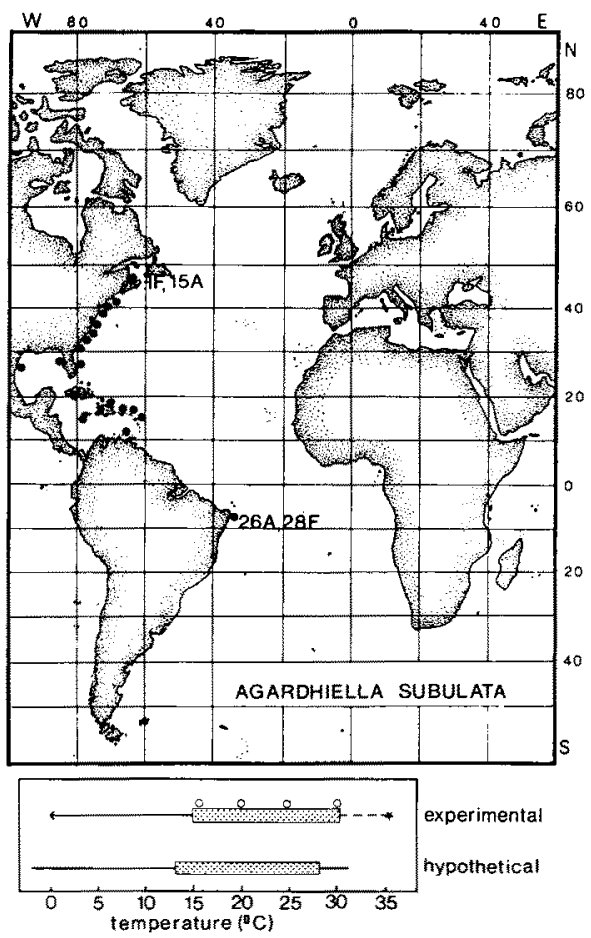

Fig. 3. The distribution of Agardhiella subulata. Map shows the geographic distribution and gives the ocean isotherms at the northern and southern boundaries. Note hypothetically derived and experimentally determined temperature ranges for growth, reproduction and survival. For rest of legend see Fig. 1. Distribution data on $A$. subulata from the following sources: Coleman \& Mathieson (1974), Edwards \& Kapraun (1973), Gabrielson \& Hommersand (1982a), Humm (1979), Mathieson \& Fuller (1969), Rhodes (1970), Schneider et al. (1979), Searles \& Schneider (1978), Sears \& Wilce (1975), South \& Cardinal (1970), Taylor (1957, 1960), Zaneveld (1972)

tion) or a $-1{ }^{\circ} \mathrm{C}$ February isotherm (corresponding with a minimum lethal temperature of $-1.8^{\circ} \mathrm{C}$ ). The ability of $A$. subulata to penetrate into the tropics indicates it will grow and reproduce at temperatures as high as $28^{\circ} \mathrm{C}$ and survive at temperatures in excess of $31^{\circ} \mathrm{C}$. 


\section{Solieria tenera}

The distribution data (Fig. 4) suggest the northern boundary to be either the $10^{\circ} \mathrm{C}$ February isotherm (corresponding with a minimum lethal temperature of $8^{\circ} \mathrm{C}$ ) or the $15^{\circ} \mathrm{C}$ August isotherm in Europe corresponding with minimum summer temperatures of $13^{\circ} \mathrm{C}$ for growth and/or reproduction). The ability of $S$. tenera to penetrate the tropics indicates it will grow and reproduce at temperatures as high as $28^{\circ} \mathrm{C}$ and survive at temperatures in excess of $31^{\circ} \mathrm{C}$.

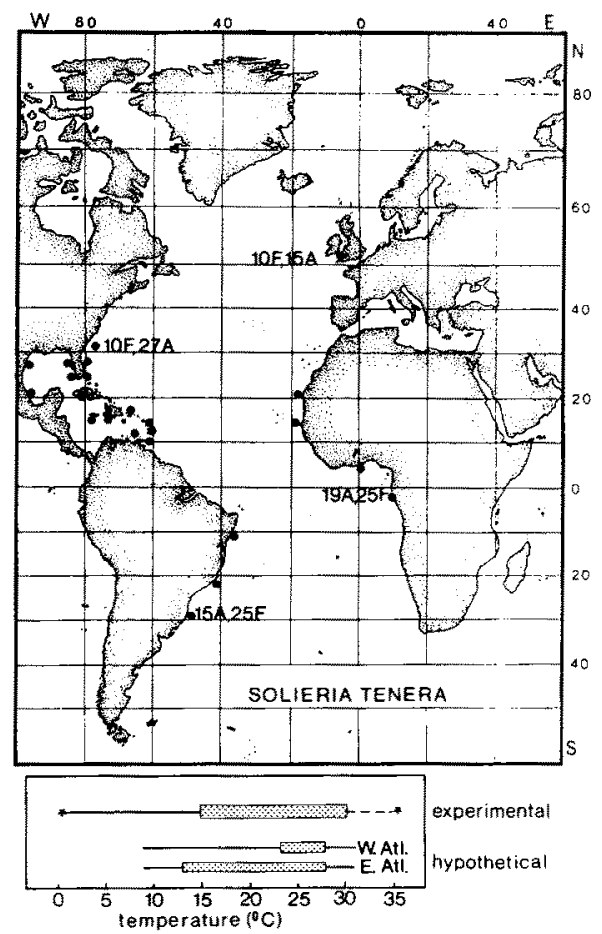

Fig. 4. The distribution of Solieria tenera. Map shows the geographic distribution and gives the ocean isotherms at the northern and southern boundaries. Note hypothetically derived and experimentally determined temperature ranges for growth and survival. For rest of legend see Fig. 1. Distribution data on $S$. tenera from the following sources: Bodard \& Mollion (1974), CordeiroMarino (1978), Dawes (1974), Edwards \& Kapraun (1973), Farnham (1980), Feldmann (1951), Gabrielson \& Hommersand (1982b), Hamm \& Humm (1976), Juett et al. (1976), Lawson \& John (1977, 1982), Oliveira Filho (1977), Searles \& Schneider (1978)

\section{The warm temperate Mediterranean Atlantic group}

\section{Halurus equisetifolius}

The distribution data (Fig. 5) suggest that the northern boundary is a lethal one at the $7{ }^{\circ} \mathrm{C}$ February isotherm (which corresponds with a $6{ }^{\circ} \mathrm{C}$ minimum water temperature). If it were at $13^{\circ} \mathrm{C}$ August isotherm (a growth and/or reproduction limit) then $H$. equisetifolius would be expected in the North Sea south to the $13^{\circ} \mathrm{C}$ August isotherm. In 


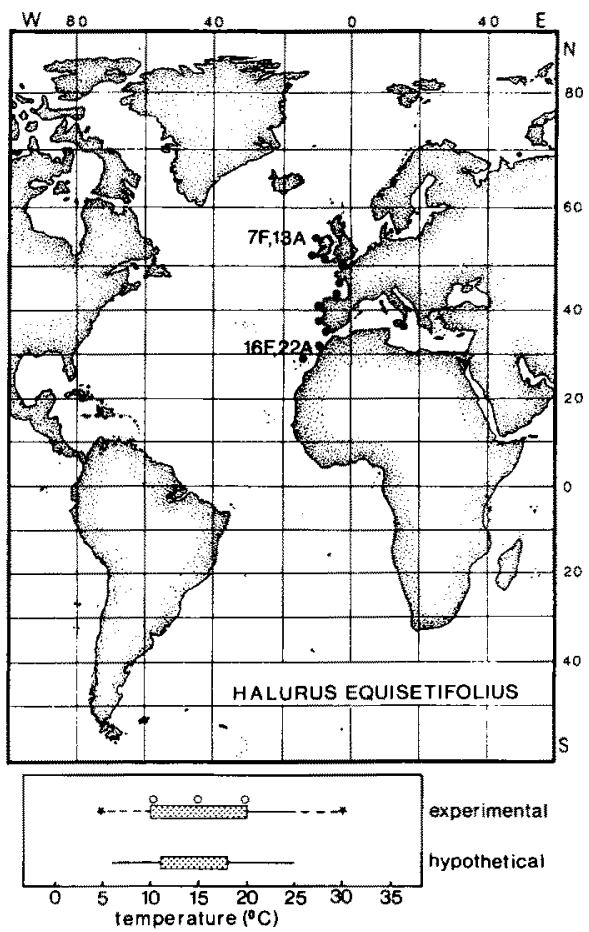

Fig. 5. The distribution of Halurus equisetifolius. Map shows the geographic distribution and gives the ocean isotherms at the northern and southern boundaries. Note hypothetically derived and experimentally determined temperature ranges for growth, reproduction and survival. For rest of legend see Fig. 1. Distribution data on $H$. equisetifolius from the following sources: Ardré (1970, 1971), Dangeard (1949), Donze (1968), Feldmann (1954), Gayral (1958), Giaccone \& Longo (1976), Guiry (1978), den Hartog (1959), van den Hoek (1982a), van den Hoek \& Donze $(1966,1967)$, Lawson \& John (1977), Meunier (1965), Newton (1931), Norton (1970), Norton \& Powell (1979), Parke \& Dixon (1976), Perez-Cirera (1975a), Prud'homme van Reine (unpubl. obs.), Rijksherbarium, Leiden; Russell (1968), Seoane-Camba (1965)

that case it could also be expected in Northeast America. The southern boundary is either a $16^{\circ} \mathrm{C}$ February isotherm (corresponding with a maximum temperature of $18^{\circ} \mathrm{C}$ permitting growth and/or reproduction) or a $22^{\circ} \mathrm{C}$ August isotherm (corresponding) with a $25^{\circ} \mathrm{C}$ summer lethal temperature). If the latter case is the real boundary, one would expect $H$. equisetifolius on the Canaries, Madeira and the Azores. In the Mediterranean, it is restricted to $0-2 \mathrm{~m}$ or greater depths in the Straits of Messina, indicating a boundary of summer lethal temperatures at $25^{\circ} \mathrm{C}$.

\section{Callophyllis laciniata}

The distribution data (Fig. 6) suggest that the northern boundary is a lethal one at the $4{ }^{\circ} \mathrm{C}$ February isotherm (which corresponds with a $3{ }^{\circ} \mathrm{C}$ minimum winter temperature). At its northern boundary in Bohuslån, southwest Sweden, it grows at depths of $15-20 \mathrm{~m}$. The surface water may cool here to temperatures lower than $2{ }^{\circ} \mathrm{C}$. If it were a $11^{\circ} \mathrm{C}$ August isotherm (a growth and/or reproduction limit) then $C$. laciniata would be 


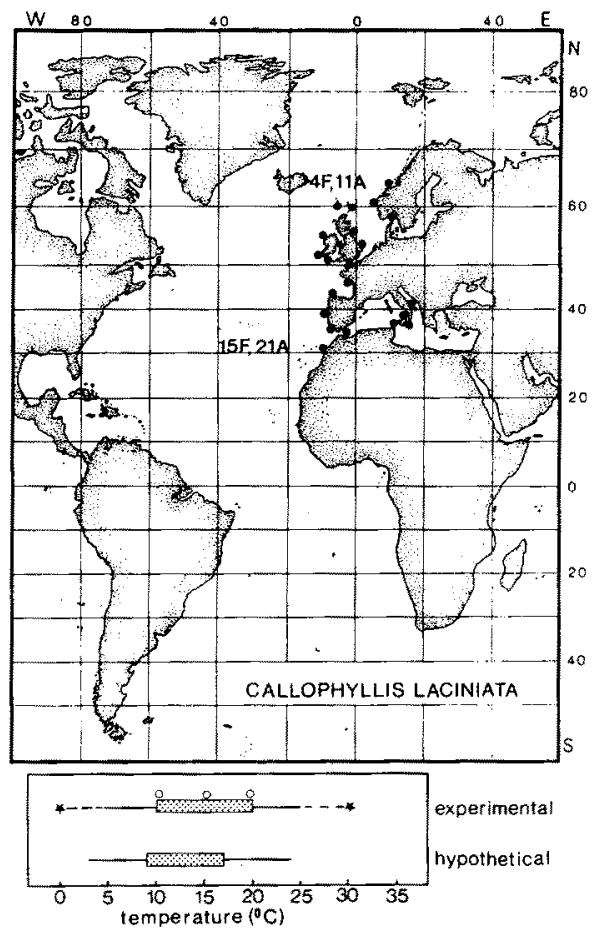

Fig. 6. The distribution of Callophyllis laciniata. Map shows the geographic distribution and gives the ocean isotherms at the northern and southern boundaries. Note hypothetically derived and experimentally determined temperature ranges for growth, reproduction and survival. For rest of legend see Fig. 1. Distribution data on C. laciniata from the following sources: Ardre $(1970,1971)$, Cinelli et al. (1979), Conde (1984), Cormaci \& Furnari (1979), Cullinane \& Whelan (1983), Dangeard (1949), Donze (1968), Egan (1983), Feldmann (1943, 1954), Gayral (1958), Giaccone (1978), Giaccone \& Longo (1976), Guiry (1978), van den Hoek (1982a), van den Hoek \& Donze (1966, 1967), Irvine, D. (1982), Irvine, L. (1983), Kain (1982), Levring (1974), Maggs et al. (1983), Norton (1976), Norton \& Powell (1979), Parke \& Dixon, (1976), Perez-Cirera (1975a, 1975b), Rueness (1977), Russell

(1961-1962), Russell (1968), Tittley et al (1976)

expected on the Danish coasts and on Helgoland, where summer temperatures arise above $11^{\circ} \mathrm{C}$. In that case it would also be expected in Northeast America. The southern boundary is either a $15^{\circ} \mathrm{C}$ February isotherm (corresponding with a maximum temperature of $17^{\circ} \mathrm{C}$ permitting growth and/or reproduction) or a $21^{\circ} \mathrm{C}$ August isotherm (corresponding with a $24^{\circ} \mathrm{C}$ summer lethal temperature). This lethal temperature seems to restrict Callophyllis to a few areas in the Mediterranean, where it grows at greater depths $(15-60 \mathrm{~m})$.

\section{Hypoglossum woodwardii}

The distribution data (Fig. 7) suggest that the northern boundary is a lethal one at the $6{ }^{\circ} \mathrm{C}$ February isotherm (which corresponds to a $5{ }^{\circ} \mathrm{C}$ minimum winter temperature). If it were a $12{ }^{\circ} \mathrm{C}$ August growth and reproduction limit, one would expect it throughout the North Sea south to the $12^{\circ} \mathrm{C}$ August isotherm and possibly in Northeast America. The 


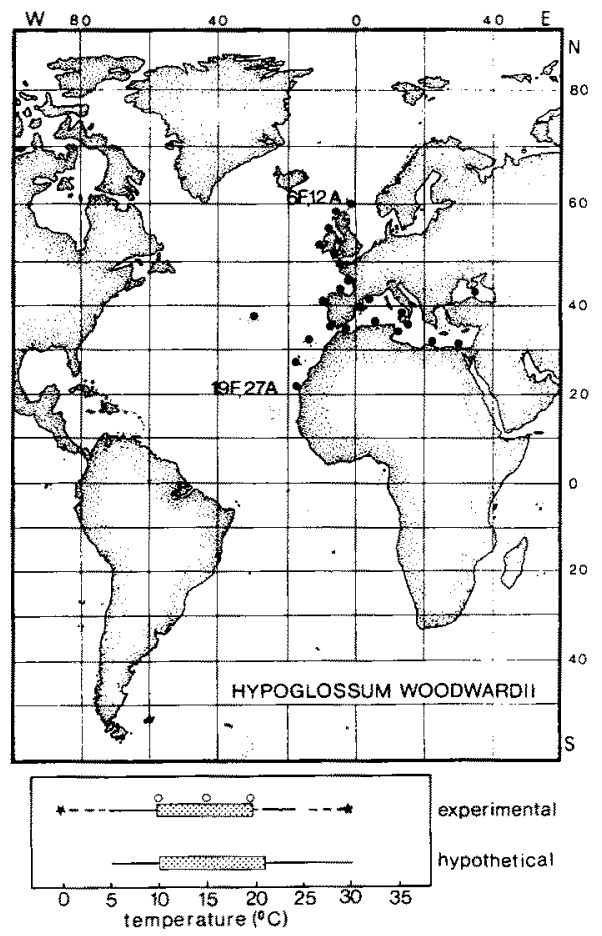

Fig. 7. The distribution of Hypoglossum woodwardii. Map shows the geographical distribution and gives the ocean isotherms at the northern and southern boundaries. Note hypothetically derived and experimentally determined temperature ranges for growth, reproduction and survival. For rest of legend see Fig. 1. Distribution of $H$. woodwardii from the following sourves: Ardré (1970), Ballisteros i Sagarra \& Martinengo (1982), Bodard \& Mollion (1974), Boudouresque \& Perret (1977), Cinelli et al. (1979), Conde (1984), Cormaci \& Furnari (1979), Cullinane \& Whelan (1983), Donze (1968), Edelstein (1964), Edwards (1975), Edwards et al, (1975), Egan (1983), Feldmann (1931, 1937, 1939, 1941, 1942, 1943, 1954), Gayral (1958), Gerloff \& Geissler (1974), Giaccone (1969, 1972, 1978), Giaccone \& Longo (1976), Gil-Rodriguez \& Afonso-Carrillo (1980), Guiry (1978), den Hartog (1959), van den Hoek (1982a), van den Hoek \& Donze (1966, 1967), Kain (1960), Lawson \& John (1977), Levring (1974), Maggs et al. (1983), Meñez \& Mathieson (1981), Meunier (1956), Navarro \& Uriarte (1945), Nizamuddin et al. (1979), Norton (1976), Norton \& Powell (1979), Parke \& Dixon (1976), Perez-Cirera (1975a), Russell (1968), Schmidt (1931), Seoane-Camba (1960, 1965), Tittley et al.

(1976), Zinova (1967)

southern boundary is either a $19^{\circ} \mathrm{C}$ February isotherm (corresponding with a maximum temperature of $21^{\circ} \mathrm{C}$ permitting growth and/or reproduction) or a $27^{\circ} \mathrm{C}$ August isotherm (corresponding with a $30^{\circ} \mathrm{C}$ summer lethal temperature).

\section{MATERIAL AND METHODS}

Carpospores of each of six red algal species ( $S$. tenera excluded) were isolated into unialgal culture. Several isolates ( $\leqslant 15$ ) of each species were established, however, culture experiments employed only one representative isolate. A vegetatively isolated strain of $S$. tenera was obtained from the University of Texas, Culture Collection (Austin, 
Table 1. The isolates of benthic marine red algae utilized in this study: their habitats, locations and dates of isolation

\begin{tabular}{|c|c|c|c|}
\hline Species & Isolate & $\begin{array}{l}\text { Place and date } \\
\text { of collection }\end{array}$ & Habitat \\
\hline $\begin{array}{l}\text { Grinnellia americana } \\
\text { (C. Ag.) Harv. }\end{array}$ & GA-13 & $\begin{array}{l}\text { Waterford, CT, USA, } \\
\text { July } 7,1983\end{array}$ & $\begin{array}{l}\text { On jetty, upper } \\
\text { sublittoral zone }\end{array}$ \\
\hline $\begin{array}{l}\text { Lomentaria baileyana } \\
\text { (Harv.) Farlow }\end{array}$ & LUS-13 & $\begin{array}{l}\text { Waterford, CT, USA } \\
\text { July } 29,1983\end{array}$ & $\begin{array}{l}\text { On jetty, lower } \\
\text { eulittoral zone }\end{array}$ \\
\hline $\begin{array}{l}\text { Agardhiella subulata } \\
\text { (C. Ag.) Kraft et Wynne }\end{array}$ & AS- 17 & $\begin{array}{l}\text { Waterford, CT, USA, } \\
\text { July } 7,1983\end{array}$ & $\begin{array}{l}\text { On jetty, upper } \\
\text { sublittoral zone }\end{array}$ \\
\hline $\begin{array}{l}\text { Solieria tenera } \\
\text { (J. Ag.) Wynne et Taylor }\end{array}$ & $\mathrm{ST}-1^{*}$ & $\begin{array}{l}\text { Port Isabel, Browns- } \\
\text { ville, Tx, USA }\end{array}$ & $\begin{array}{l}\text { On jetty, } \\
\text { sublittoral zone }\end{array}$ \\
\hline $\begin{array}{l}\text { Halurus equisetifolius } \\
\text { (Lightfoot) Kütz. }\end{array}$ & $\mathrm{H}-2$ & $\begin{array}{l}\text { Roscoff, France, } \\
\text { October 6, } 1983\end{array}$ & $\begin{array}{l}\text { On rocks, lower } \\
\text { eulittoral zone }\end{array}$ \\
\hline $\begin{array}{l}\text { Callophyllis laciniata } \\
\text { (Hudson) Kütz. }\end{array}$ & $\mathrm{Ca}-2$ & $\begin{array}{l}\text { Roscoff, France, } \\
\text { October 4, } 1983\end{array}$ & $\begin{array}{l}\text { Epiphytic on Laminaria } \\
\text { hyperborea, upper } \\
\text { sublittoral zone }\end{array}$ \\
\hline $\begin{array}{l}\text { Hypoglossum woodwardii } \\
\text { Kütz. }\end{array}$ & Hyp-2 & $\begin{array}{l}\text { Roscoff, France, } \\
\text { October 5, } 1983\end{array}$ & $\begin{array}{l}\text { Epiphytic on Laminaria } \\
\text { hyperborea, upper } \\
\text { sublittoral zone }\end{array}$ \\
\hline - UTEX LB 2208 & & & \\
\hline
\end{tabular}

Texas, U.S.A). Their habitats, locations and dates of isolation are listed in Table 1. Unialgal cultures were maintained in an enriched seawater medium at $33 \%$ (Provasoli, 1968). The material used in all experiments with the exception of $S$, tenera originated from tetrasporophytic plants that had been grown from isolated carpospores in culture. G. americana, $L$. baileyana, $A$. subulata and $S$. tenera were propagated by fragmentation and maintained in stock-cutlures at $20^{\circ} \mathrm{C}$ 'long day' conditions $(16: \overline{8}, \mathrm{~L}: \overline{\mathrm{D}})$, 'photon flux density' ca $20 \mu \mathrm{E} \mathrm{m}^{-2} \mathrm{~s}^{-1}$ (= ca $1000 \mathrm{~lx}$ ). C. laciniata, $H$. equisetifolius and $H$. woodwardii were also propagated by fragmentation and maintained in stock-cultures at $15^{\circ} \mathrm{C}$ 'long day' conditions, photon flux density ca $20 \mu \mathrm{E} \mathrm{m}^{-2} \mathrm{~s}^{-1}$.

A series of controlled environment incubators (Fridina) were employed (each had a $\pm 1^{\circ} \mathrm{C}$ temperature variation). Up to 41 combinations of light intensity, temperature and daylength were available for experimentation (see for instance Fig. 9). The algae were cultured in $300 \mathrm{ml}$ erlenmeyer flasks containing $250 \mathrm{ml}$ of the enriched seawater medium. The culture medium was renewed at least every other week (or sooner) to minimize changes in salinity, $\mathrm{pH}$, or depletion of nutrients.

In the first series of experiments, the growth and reproductive responses of the gametophytic and/or tetrasporophytic phases of each of the algae were studied (Table 2). About fifty carpospores or tetraspores of each alga were used as the inoculum, after some growth had taken place, the 6 or 7 largest plants in each dish were retained to continue the experiment. The inocula for cloned cultures consisted of 10 apical cuttings, $5 \mathrm{~mm}$ in length and, after some growth and cell repair had taken place, the 6 or 7 largest plants in 
Table 2. Reproductive phases studied in the cultural experiments

\begin{tabular}{|lcc|}
\hline Species & $\begin{array}{c}\text { Gametophytic } \\
\text { phase }\end{array}$ & $\begin{array}{c}\text { Tetrasporophytic } \\
\text { phase }\end{array}$ \\
\hline Grinnellia americana & + & ++ \\
Lomentaria baileyana & + & ++ \\
Agardhiella subulata & n.t. & ++ \\
Solieria tenera & ++++ & +++ \\
Halurus equisetifolius & n.t. & +++ \\
Callophyllis laciniata & n.t. & +++ \\
Hypoglossum woodwardii & + & \\
& & \\
+ from tetraspores & & \\
++ from apical cuttings of cloned culture & \\
+++ from carpospores directly isolated from field & \\
n.t. not tested & & \\
\end{tabular}

each flask were retained to continue the experiments. Growth of the algae was recorded photographically after $6-8$ weeks. All algae had an incubation time of at least four months to maximize the possibility to observe reproduction.

Long term survival was decided if the plant material could survive the extreme temperature for at least six weeks. The effects of thermal shock were tested by preincubating the experimental material for at least four days at the lowest or highest nonlethal temperatures before subjecting it again to the initially lethal extreme temperatures. Plants which did not grow or appeared dead were re-incubated at optimal temperatures $\left(15\right.$ or $\left.20^{\circ} \mathrm{C}\right)$ for at least four weeks to test their viability.

A second series of experiments was designed to quantify the growth of 4 day-old tetrasporelings of $G$, americana, $L$. baileyana and $H$. woodwardii in the controlled environment incubators. Coverslips were placed on the bottom of culture vessels prior to the inoculation of the spores to facilitate the subsequent microscopic examination of the sporelings (Edwards, 1979). Growth responses of each alga were determined from the mean cell number ( $G$. americana and $H$. woodwardii) or the length of the main axis ( $L$. baileyana) of the 15 largest sporelings in a sample of 25 sporelings. The cell numbers represent the number of cells in the axial cell row and the longest rhizoid because the sporelings became pluriseriate. Confidence limits were derived for each of these experiments.

In the incubators, four $20 \mathrm{~W}$ Philips TL 34 fluorescent tubes provided light. Photon flux density was measured with a LICor LI 185 quantameter and expressed in micro Einstein $\mathrm{m}^{-2} \mathrm{~s}^{-1}$ PAR $\left(1 \mu \mathrm{E} \mathrm{m} \mathrm{m}^{-2} \mathrm{~s}^{-1} \mathrm{PAR}=1 \mathrm{Mol}\right.$ quanta $\mathrm{m}^{-2} \mathrm{~s}^{-1}$ in the waveband 400 to 700 $\mathrm{nm})$.

Species distribution maps were compiled from all sources listed in van den Hoek (1982a) as well as from those listed in Figs 1-7. Open ocean isotherms were derived from Sverdrup et al. (1942).

Regular monthly collections and phenological observations were made over an extended period of seven years only for the three Northeast American species, $G$. americana, L. baileyana and $A$. subulata. Monthly collections were made in the vicinity 
of Millstone Point, Waterford $\left(41^{\circ} 18^{\prime} \mathrm{N}, 72^{\circ} 10^{\prime} \mathrm{W}\right)$, and Cove Island Beach, Stamford $\left(41^{\circ} 06^{\prime} \mathrm{N}, 73^{\circ} 28^{\prime} \mathrm{W}\right)$, both on the coast of Long Island Sound in Connecticut, U.S.A. Limited collection data of $H$. equisetifolius, $C$. laciniata, and $H$. woodwardii were based on Feldmann (1954) and our own scattered floristic notes of the past three years at Roscoff, France $\left(48^{\circ} 43^{\prime} \mathrm{N}, 03^{\circ} 58^{\prime} \mathrm{W}\right)$, not on any extended series of phenological observations. Since no collection data were available for $S$. tenera (which was collected at Port Isabel, Brownsville, Texas, U.S.A.), data from a site just north of Port Aransas, Texas $\left(28^{\circ} \mathrm{N} 97^{\circ} \mathrm{W}\right)$ were adapted from Edwards \& Kapraun (1973) as Agardhiella tenera.

\section{RESULTS}

The results are presented under 3 categories, namely: seasonal distribution and field observations, life history studies, and experiments with environmental factors.

\section{Seasonal distribution and field observations}

The seasonal occurrence of the species in the Northeast American tropical-totemperate group (G. americana, L. baileyana, and A. subulata) in Connecticut, U.S.A. is summarized in Table 3. Average weekly surface water temperatures (Fig. 8) at Norwalk Harbor, Norwalk, Connecticut $\left(41^{\circ} 8^{\prime} \mathrm{N}, 73^{\circ} 22^{\prime} \mathrm{W}\right)$ were calculated for the period of January, 1974 to September 1983 (courtesy of Dr. M. Kesser and J. Foertch, Northeast Utilities Service Company). The temperature varied from a low of $-1.8^{\circ} \mathrm{C}$ in February, 1979 to a high of $24^{\circ} \mathrm{C}$ in August, 1980.

Field studies revealed that $G$. americana began growth in late May - early June,

Table 3. Monthly observations on the phenology of Grinnellia americana, Lomentaria baileyana, and Agardhiella subulata in Connecticut from April, 1979 to September, 1983*, and Solieria tenera* * in Texas from July to December, 1969**

\begin{tabular}{|c|c|c|c|c|c|c|c|c|c|c|c|c|}
\hline \multirow[t]{2}{*}{ Species } & \multicolumn{12}{|c|}{ Month } \\
\hline & Jan & Feb & Mar & Apr & May & Jun & Jul & Aug & Sept & Oct & Nov & Dec \\
\hline $\begin{array}{l}\text { Grinnellia } \\
\text { americana }\end{array}$ & $\mathrm{X}, \mathrm{T}$ & - & - & - & $X, F$ & $\mathrm{x}$ & $\mathrm{x}$ & $\mathrm{X}, \mathrm{F}$ & $\mathrm{X}, \mathrm{T}$ & $\begin{array}{l}\mathrm{X}, \mathrm{T} \\
\mathrm{F}, \mathrm{M}\end{array}$ & $\begin{array}{l}X, T, \\
F\end{array}$ & $\mathrm{X}, \mathrm{F}$ \\
\hline $\begin{array}{l}\text { Lomentaria } \\
\text { baileyana }\end{array}$ & $\begin{array}{l}\mathrm{X}, \mathrm{T}, \\
\mathrm{F}\end{array}$ & - & - & - & - & - & $\begin{array}{l}X, T, \\
F\end{array}$ & $\mathrm{X}, \mathrm{T}$ & $\mathrm{X}, \mathrm{T}$ & $\mathrm{x}$ & $X, F$ & - \\
\hline $\begin{array}{l}\text { Agardhiella } \\
\text { subulata }\end{array}$ & - & $\mathrm{X}$ & $\mathrm{x}$ & $\mathrm{x}$ & $\begin{array}{l}X, T \\
F\end{array}$ & $\mathrm{X}, \mathrm{F}$ & $\mathrm{X}, \mathrm{T}$ & $\begin{array}{l}X, T \\
F, M\end{array}$ & $\begin{array}{l}\mathrm{X}, \mathrm{T} \\
\mathrm{F}, \mathrm{M}\end{array}$ & $\begin{array}{l}\mathrm{X}, \mathrm{T} \\
\mathrm{F}, \mathrm{M}\end{array}$ & $X, F$ & $X, F$ \\
\hline $\begin{array}{l}\text { Solieria } \\
\text { tenera }\end{array}$ & $X, F$ & $x$ & $x$ & - & $\mathrm{X}, \mathrm{T}$ & $\begin{array}{l}X, T, \\
F\end{array}$ & $\begin{array}{l}X, T \\
F, M\end{array}$ & $\begin{array}{l}X, T \\
F\end{array}$ & $\begin{array}{l}\mathrm{X}, \mathrm{F} \\
\mathrm{M}\end{array}$ & $T, F$ & $T, F$ & $X, F$ \\
\hline $\begin{array}{l}\text { In part fro } \\
\therefore \text { Edwards } \\
\text { T, Tetraspora } \\
\text { X, Vegetative } \\
\text { M, Male } \\
\text { F, Female } \\
\text { and/or Carpo } \\
\text { - Apparentl }\end{array}$ & $\begin{array}{l}\text { unpub } \\
\text { Kaprau } \\
\text { jium }\end{array}$ & $\begin{array}{l}\text { lished } \\
\text { n (197 }\end{array}$ & o b & r. $M$. & osser & & rtch, $N$ & rrtheas & til & $\mathrm{Se}$ & c & any \\
\hline
\end{tabular}




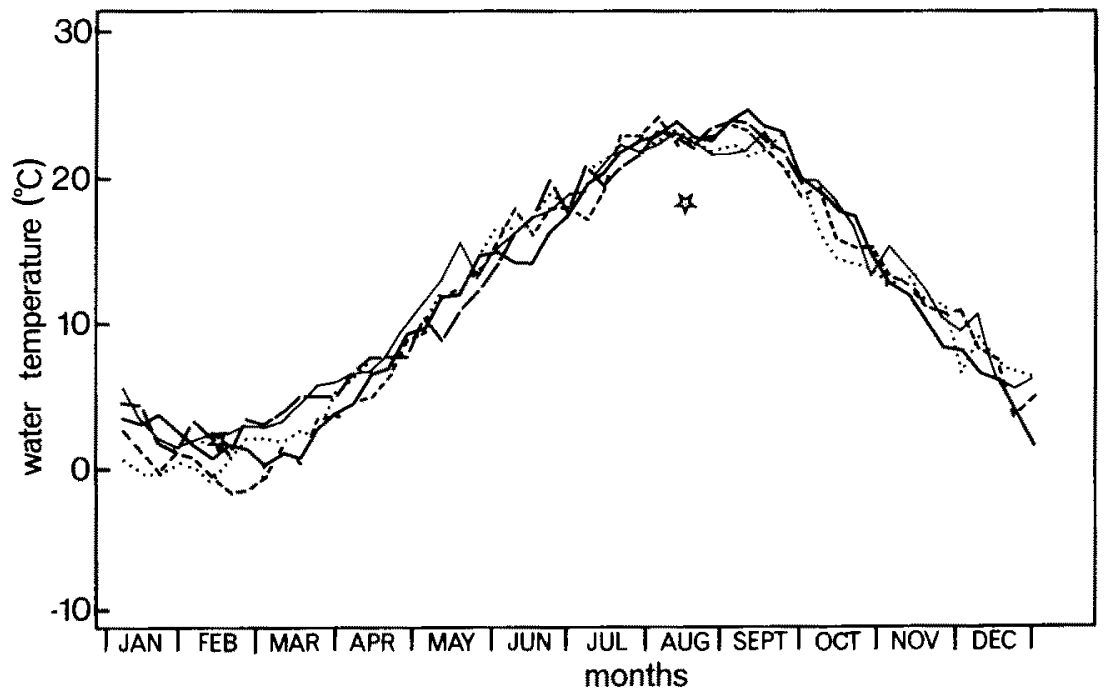

Fig. 8. The average weekly water temperature from January, 1979 to September, 1983 in Norwalk Harbor, Norwalk, CT $\left(41^{\circ} 08^{\prime} \mathrm{N}, 73^{\circ} 22^{\prime} \mathrm{W}\right)$. Data supplied by Dr. M. Kesser and J. Foertch, Northeast Utilities Service Company. The gives the open ocean isotherms in winter and summer for this latitude and longitude (Sverdrup et al., 1942). Legends: $---1979_{;}-1980_{;} \ldots 1981_{;}-$ $1982 ;$ and - 1983

reached maximal growth in the upper sublittoral zone in late August and even persisted in the study area through January as minute plants. Specimens were infrequently collected in winter and were only a few centimeters in length. Tetrasporophytic phases were collected in September through November. Vegetative material brought back into the laboratory in January, eventually produced tetrasporangia. Female and/or carposporophytic material were collected in May, August and October - early December. Antheridial plants were only found on one occasion in early October.

L. baileyana began growth in late July and persisted in the region in abundance until September. Plants were collected occasionally in October and November and those found in the winter had an extremely well developed discoid basal system with an upright axis $<2 \mathrm{~cm}$. Tetrasporophytic plants dominated collections and were usually found in late July-August. In some years tetrasporophytic material was collected in September and on one occasion in January. Carposporophytic material was found in late July and unfertilised gonimoblasts were found in November and January. Antheridial plants were never found during the study period.

A. subulata could be collected throughout most of the year (Table 3), if established populations were sampled. Plants in the winter and late summer were usually $<2 \mathrm{~cm}$ in length with an extremely well developed basal system. Growth began in late May and continued into October. Tetrasporophytic and carposporophytic phases were found throughout the growing season. Antheridial plants were usually collected in August-October.

The phenology of $S$, tenera, the sole representative of the amphiatlantic tropical-towarm temperate group with a northeastern extension, has been adopted from Edwards \& 
Kapraun (1973; as A. tenera) and is given in Table 3. Plants were found throughout the year at Port Aransas, Texas, U.S.A. except in April. According to Edwards \& Kapraun (1973) $S$. tenera (as $A$, tenera) was seasonally dominant in the summer-autumn period on the Port Aransas jetty when the mean monthly temperature varied from $25-30^{\circ} \mathrm{C}$ (June-October). According to Edwards \& Kapraun (1973) the annual temperature variation at Port Aransas, Texas between the mean February and the mean August temperature was $12.7-30^{\circ} \mathrm{C}$.

The seasonal occurrence of the species in the warm temperate Mediterranean Atlantic group ( $H$. equisetifolius, $C$. laciniata and $H$. woodwardii) from Roscoff, France is summarized in Table 4. The data in Table 4 are based upon Feldmann (1954) and our

Table 4. Seasonal observations on the phenology of Halurus equisetifolius, Callophyllis laciniata, and Hypoglossum woodwardii in Roscoff, France*

\begin{tabular}{|lllll|}
\hline \multicolumn{1}{|c}{ Species } & Spring & Summer & Fall & Winter \\
\hline Halurus equisetifolius & $\mathrm{X} *$ & $\mathrm{X}$ & $\mathrm{X}, \mathrm{T}, \mathrm{F}, \mathrm{M}$ & $\mathrm{X}$ \\
Callophyllis laciniata & $\mathrm{X}, \mathrm{F}$ & $\mathrm{T}$ & $\mathrm{X}, \mathrm{T}, \mathrm{F}$ & $\mathrm{F}$ \\
Hypoglossum woodwardii & $\mathrm{X}, \mathrm{T}, \mathrm{F}, \mathrm{M}$ & $\mathrm{T}, \mathrm{F}$ & $\mathrm{X}, \mathrm{T}, \mathrm{F}$ & $\mathrm{T}, \mathrm{F}$ \\
* In part, after Feldmann (1954) & & & & \\
- T, Tetrasporangium; X, Vegetative; M, Male; F, Female and/or carposporophyte. \\
\hline
\end{tabular}

own scattered floristic notes of the past three years. There are no extended series of phenological observations available from the study site. The annual temperature variation between the mean February and the mean August temperature over a 10 year period was $8-15.6^{\circ} \mathrm{C}$ (Le laboratoire de l'I.S.T.P.M. de Roscoff, 1976). Each of the taxa was perennial at Roscoff. Collection data indicate that the tetrasporophytic and carposporophytic phases of $H$. equisetifolius occur in the fall. The tetrasporophytic phase of $C$. laciniata was found in the summer through the fall, whereas the carposporophytic phase was found in winter, spring and fall. The tetrasporophytic and carposporophytic phases of $H$. woodwardii occurred throughout the year in the study area.

\section{Life history studies}

The members of the northeast American tropical-to-temperate group (G. americana, $L$. baileyana and $A$. subulata) demonstrated a modified isomorphic alternation of generations. The tetrasporophytic phase of $G$. americana successfully produced the gametophytic phase. The only modification of this was that all tetrasporophytic isolates produced stalked cystocarpic structures at temperatures $<20^{\circ} \mathrm{C}$. The tetrasporophytic phase of $L$. baileyana produced tetraspores, all of which grew into non-reproductive vegetative plants under all experimental conditions. The putative gametophytes fragmented at 20-30 ${ }^{\circ} \mathrm{C}, 40 \mu \mathrm{E} \mathrm{m} \mathrm{m}^{-2} \mathrm{~s}^{-1}, 16: \overline{8} \mathrm{~L}: \mathrm{D}$, thereby indicating a potential means of asexual reproduction. Only $A$. subulata successfully demonstrated an isomorphic alternation of generations.

The only member of the amphiatlantic tropical-to-warm temperate group investigated was an isolate of $S$. tenera. It remained vegetative throughout the study. This 
isolate had originally been derived from a non-reproductive plant by cuttings of the apical tip (B. Bacu, pers. comm.).

The members of the warm temperate Mediterranean Atlantic group include: $H$. equisetifolius, $C$. laciniata and $H$. woodwardii. Each of the tetrasporophytic phases derived from carposporelings became reproductive and their life histories are still under investigation.

\section{Experiments with environmental factors}

\section{The Northeast American tropical-to-temperate group}

\section{Grinnellia americana}

Growth and/or survival of the tetrasporophytic and gametophytic phases of $G$. americana proceeded over a broad range of light intensities and temperatures from 10 to $40 \mu \mathrm{E} \mathrm{m} \mathrm{m}^{-2} \mathrm{~s}^{-1}$ and $0-30^{\circ} \mathrm{C}$ (Fig. 9). Good growth occurred between $15-30^{\circ} \mathrm{C}$. The tetrasporophytic and gametophytic phases each survived at $35^{\circ} \mathrm{C}$ up to $14 \mathrm{~d}$, with plants growing at $40 \mu \mathrm{E} \mathrm{m} \mathrm{m}^{-2} \mathrm{~s}^{-1}$ surviving $2 \mathrm{~d}$ longer than ones growing at $20 \mu \mathrm{E} \mathrm{m} \mathrm{m}^{-2} \mathrm{~s}^{-1}$. The gametophytic phase at $5-10^{\circ} \mathrm{C}$ survived a broader range of light conditions than the tetrasporophytic phase. In each case, plants at $5^{\circ} \mathrm{C}, 8: \overline{16}, \mathrm{~L}: \overline{\mathrm{D}}$, survived longer than the plants at $5^{\circ} \mathrm{C}, 16: \overline{8}, \mathrm{~L}: \overline{\mathrm{D}}$, thereby indicating chilling damage. Plants of each phase continued to survive $0{ }^{\circ} \mathrm{C}$ for periods of over four months under $8: \overline{16}, L: \bar{D}$.

Spermatangia and carpogonia, and carposporophytic development of $G$ americana occurred in $10-40 \mu \mathrm{E} \mathrm{m}^{-2} \mathrm{~s}^{-1}$ and at $15-30^{\circ} \mathrm{C}$ (Fig. 9). Plants under 16: $\overline{8}, \mathrm{~L}: \overline{\mathrm{D}}$ matured faster $(36 \mathrm{~d})$ than ones under $8: \overline{16}, \mathrm{~L}: \overline{\mathrm{D}}(36-47 \mathrm{~d})$. Plants growing at higher temperatures $\left(20-30^{\circ} \mathrm{C} ; 16: \overline{8}, \mathrm{~L}: \overline{\mathrm{D}}\right)$ matured faster than ones growing at $15^{\circ} \mathrm{C}(16: \overline{8}, \mathrm{~L}: \overline{\mathrm{D}})$, i.e. 36 versus $50 \mathrm{~d}$ respectively. The tetrasporophytic phase reproduced under a more restricted set of temperature conditions than the gametophytic phase, from $20-30{ }^{\circ} \mathrm{C}$. Plants growing at $30^{\circ} \mathrm{C}$ and at $40 \mu \mathrm{E} \mathrm{m}^{-2} \mathrm{~s}^{-1} ; 16: \overline{8}, \mathrm{~L}: \overline{\mathrm{D}}$ matured faster than ones growing at $20^{\circ} \mathrm{C} ; 24$ versus $33 \mathrm{~d}$ respectively. At higher temperatures $\left(\geqq 25-30^{\circ} \mathrm{C}\right)$ maturation was faster and was followed by the disintegration of the upright thallus. Plants growing at $20^{\circ} \mathrm{C}$ at $40 \mu \mathrm{E} \mathrm{m}{ }^{-2}$ $\mathrm{s}^{-1} ; 16: \overline{8}, \mathrm{~L}: \overline{\mathrm{D}}$ matured in $33 \mathrm{~d}$ whereas ones at $10 \mu \mathrm{E} \mathrm{m}^{-2} \mathrm{~s}^{-1}, 16: \overline{8}, \mathrm{~L}: \overline{\mathrm{D}}$ took $53 \mathrm{~d}$ to mature. Plants grown under $16: \overline{8}, L: \bar{D}$ matured faster than plants grown under $8: \overline{16}, L: \bar{D}$ at corresponding light and temperature conditions (i.e. at $25^{\circ} \mathrm{C}, 40 \mu \mathrm{E} \mathrm{m} \mathrm{m}^{-2} \mathrm{~s}^{-1}$, plants matured in $33 \mathrm{~d}$ under $16: \overline{8}, \mathrm{~L}: \overline{\mathrm{D}}$ compared to plants which took $90 \mathrm{~d}$ under $8: \overline{16}, \mathrm{~L}: \overline{\mathrm{D}}$ ). At $15^{\circ} \mathrm{C}$ stalked projections which eventually developed into cystocarps were produced. The plants at $15^{\circ} \mathrm{C}(8: \overline{16}, \mathrm{~L}: \overline{\mathrm{D}})$ produced cystocarpic structures which released spores only after $120 \mathrm{~d}$. Plants which produced these projections under $16: \overline{8}, \mathrm{~L}: \overline{\mathrm{D}}$ failed to mature within the experimental period. This unusual life cycle modification is currently under further investigation.

The growth of carposporelings of $G$. americana was maximal at $40 \mu \mathrm{E} \mathrm{m} \mathrm{m}^{-2} \mathrm{~s}^{-1}$ and at $25^{\circ} \mathrm{C}$. However, the sporelings grew over a wide range of light, temperature and daylength regimes (Fig. 10). Sporelings continued to survive temperatures as low as $0{ }^{\circ} \mathrm{C}$. Sporelings at $5^{\circ} \mathrm{C}, 8: \overline{16}, \mathrm{~L}: \overline{\mathrm{D}}$ survived and had some growth as compared to ones at $5^{\circ} \mathrm{C}, 16: \overline{8}, \mathrm{~L}: \overline{\mathrm{D}}$, all of which died which indicates chilling damage. All sporelings failed to survive at $35^{\circ} \mathrm{C}$. 


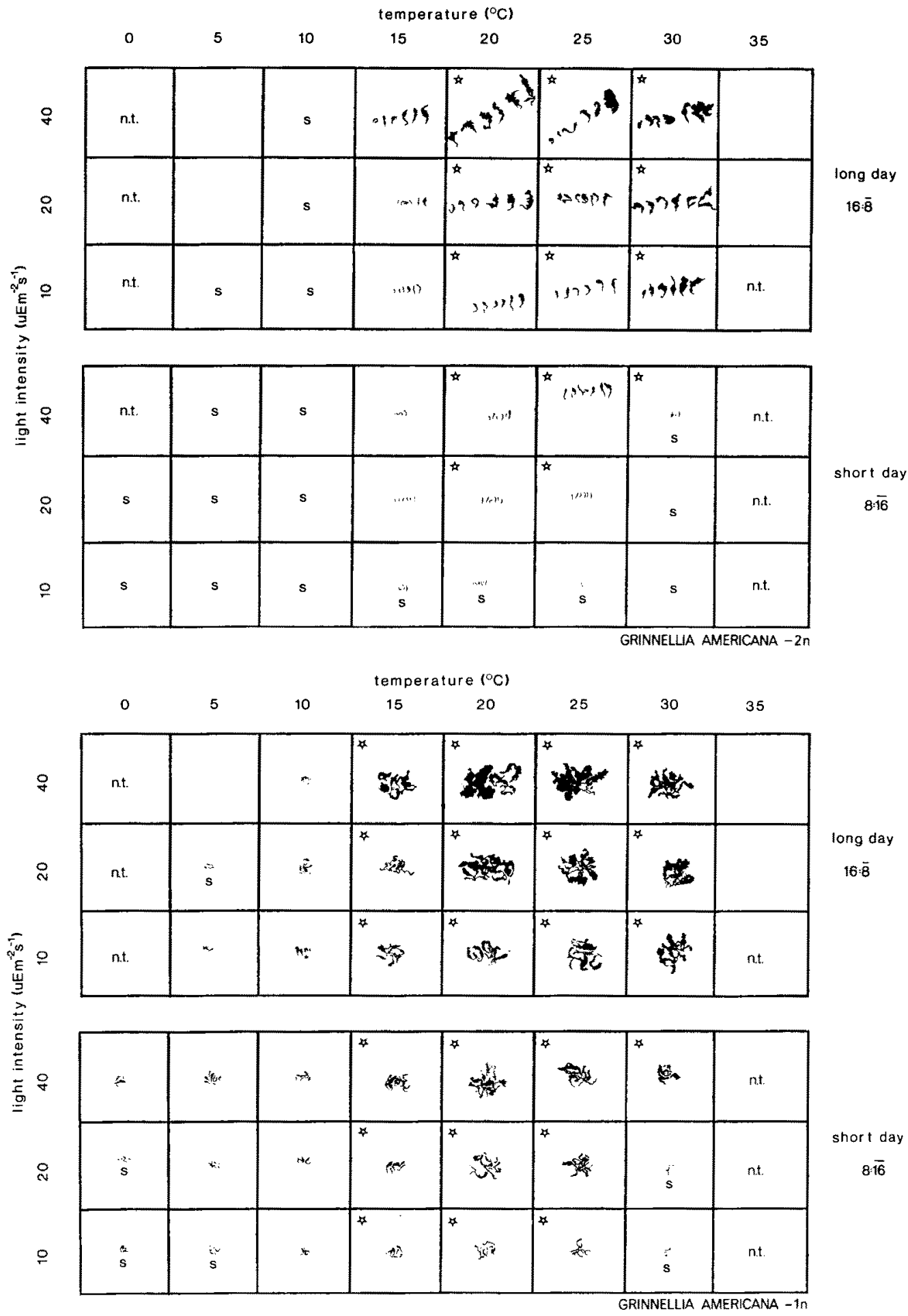

Fig. 9. The growth response of the gametophytic (36d) and the tetrasporophytic phases (after 33d) of G. americana to varying light, temperature and photoperiodic regimes. The algae were placed on a plexiglass plate in a dish with sterilized seawater and photographed. The experiment was continued for $120 \mathrm{~d}$. The symbols are as follows: (t) reproduction and spore release; (S) survived at least $42 d_{\text {i }}$ (n.t.) condition not tested. Scale: $2 \mathrm{n}$-plants: $1 \mathrm{~mm}=7 \mathrm{~mm}$; $1 \mathrm{n}$-plants: $1 \mathrm{~mm}=6 \mathrm{~mm}$ 


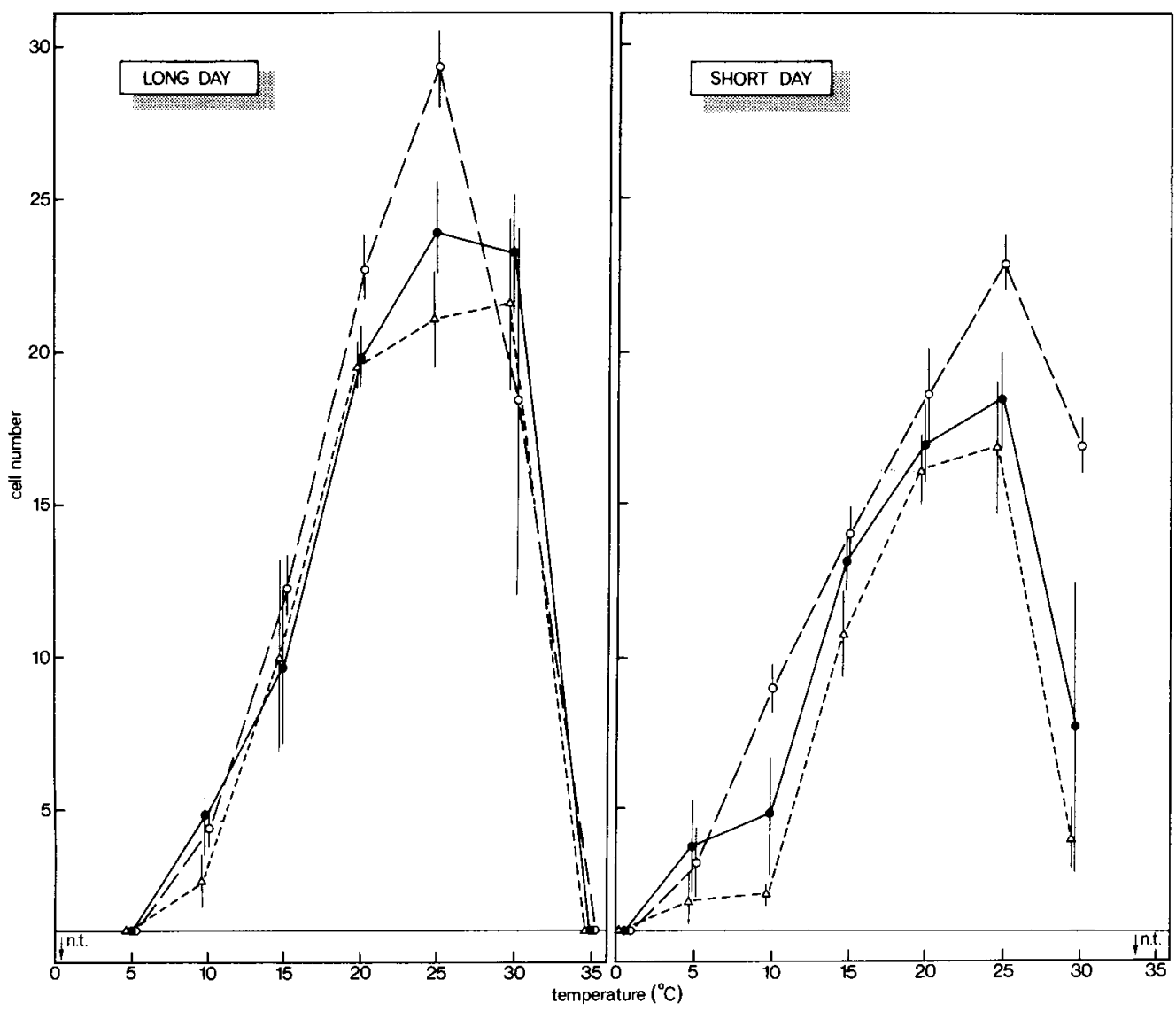

Fig. 10. The growth of G. americana expressed as the mean cell number of 15 tetrasporelings (with confidence limits) to varying light, temperature and photoperiodic regimes after $4 \mathrm{~d}$. The solid horizontal line in the lower portion of the graph represents the mean number of cells of the inoculum. The symbols are as follows: $(0--0) 40 \mu \mathrm{E} \mathrm{m}^{-2} \mathrm{~s}^{-1}$; $\longrightarrow 20 \mu \mathrm{E} \mathrm{m}^{-2} \mathrm{~s}^{-1} ;(\Delta---\Delta) 10 \mu \mathrm{E}$ $\mathrm{m}^{-2} \mathrm{~s}^{-1}$; and (n.t.) no tested

\section{Lomentaria baileyana}

Growth and/or survival of the tetrasporophytic and gametophytic phases of $L$. baileyana proceeded over a broad range of light intensities and temperatures from 10-40 $\mu \mathrm{E} \mathrm{m} \mathrm{m}^{-2} \mathrm{~s}^{-1}$ and $0-30^{\circ} \mathrm{C}$ (Fig. 11). Good growth occurred between $15-30^{\circ} \mathrm{C}$. The tetrasporophytic and gametophytic phases each survived $35^{\circ} \mathrm{C}$ less than 12 days. The tetrasporophytic phase survived longer at $5^{\circ}, 16: \overline{8}, \mathrm{~L}: \overline{\mathrm{D}}$, and at all light intensities tested as compared to the gametophytic phase. At $30^{\circ}, 8: \overline{16}, \mathrm{~L}: \overline{\mathrm{D}}$, the gametophytic phase had a higher survival potential at 10 and $20 \mu \mathrm{E} \mathrm{m}^{-2} \mathrm{~s}^{-1}$ than the tetrasporophytic phase. Plants of each phase continued to survive $0^{\circ}$ for periods of up to $60 \mathrm{~d}$. At higher temperatures maturation was faster and was followed by the disintegration of the upright thallus. At temperatures $\leqq 15^{\circ} \mathrm{C}$ there was development of a discoid basal system. The tetrasporophytic phase displayed a greater growth yield than the gametophyte. 


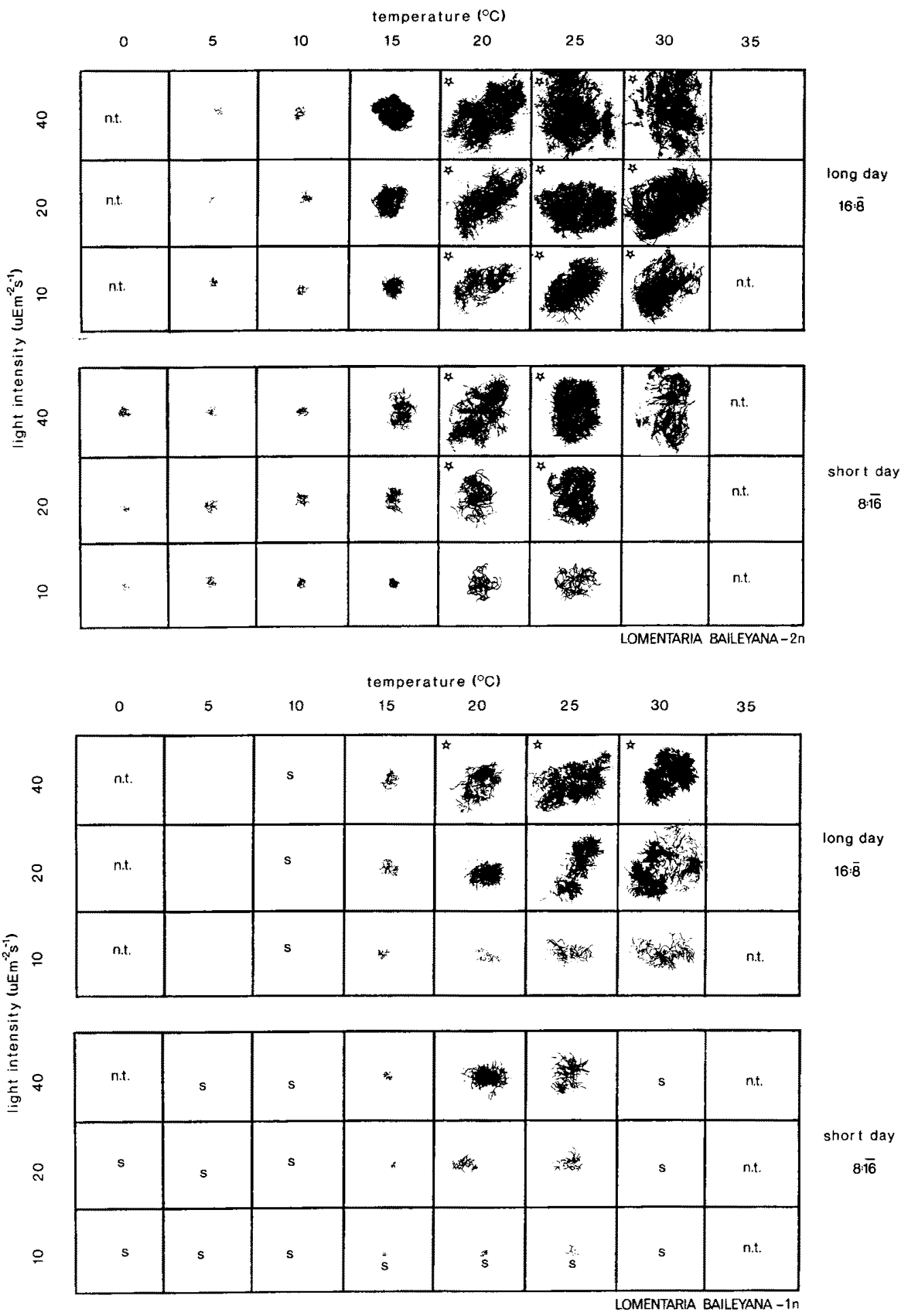

Fig. 11. The growth response of the gametophytic (after 46d) and the tetrasporophytic phases (after $40 \mathrm{~d})$ of $L$. baileyana to varying light, temperature and photoperiodic regimes. Experiment was continued for 120 d. Symbols as in Fig. 9. Note, the for the gametophytic phase only refers to fragmentation as the sole means for reproduction. Scale: $2 \mathrm{n}$-plants: $1 \mathrm{~mm}=6 \mathrm{~mm}$; $1 \mathrm{n}$-plants: 
Spermatangia and carpogonia failed to occur under all the experimental regimes. Plants remained vegetative throughout the study period. Temperature shock and nutrient depletion of the culture media did not stimulate any reproductive structures. At $40 \mu \mathrm{E} \mathrm{m} \mathrm{m}^{-2} \mathrm{~s}^{-1}$ and at $20-30^{\circ} \mathrm{C}$ (for $16: \overline{8}, \mathrm{~L}: \overline{\mathrm{D}}$ grown plants) plants fragmented (Fig. 11). This indicates that vegetative fragmentation of the gametophytic phase may be an important means of asexual reproduction. The tetrasporophytic phase produced tetrasporangia in $10-40 \mu \mathrm{E} \mathrm{m} \mathrm{m}^{-2} \mathrm{~s}^{-1}$ and at $20-30^{\circ} \mathrm{C}$ (Fig. 4). Plants under $16: \overline{8}, \mathrm{~L}: \overline{\mathrm{D}}$ matured faster $(14 \mathrm{~d})$ than ones under $8: \overline{16}, L: \overline{\mathrm{D}}(60 \mathrm{~d})$. Plants growing at $40 \mu \mathrm{Em}^{-2} \mathrm{~s}^{-1}$ under $16: \overline{8}$, $\mathrm{L}: \overline{\mathrm{D}}$ matured faster $(14 \mathrm{~d})$ than ones growing at $10 \mu \mathrm{E} \mathrm{m} \mathrm{m}^{-2} \mathrm{~s}^{-1}(26 \mathrm{~d})$ at $20-30^{\circ} \mathrm{C}$.

The growth of tetrasporelings of $L$. baileyana was maximal at $40 \mu \mathrm{E} \mathrm{m} \mathrm{m}^{-2} \mathrm{~s}^{-1}$ and at $25^{\circ} \mathrm{C}$. However, the sporelings grew over a wide range of light, temperature and daylength regimes (Fig. 12). As temperature increased, the growth of the tetrasporelings

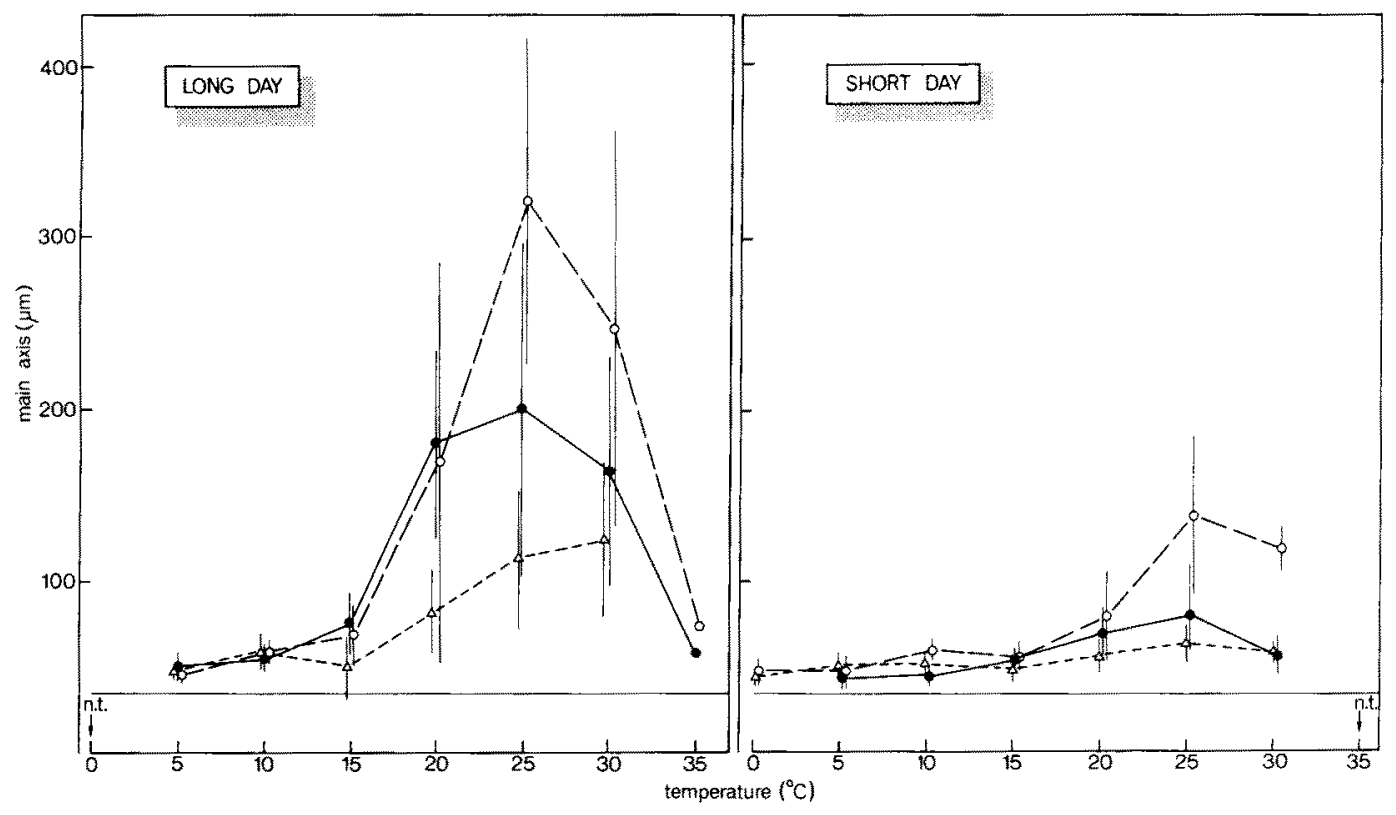

Fig. 12. The growth of $L$. baileyana expressed as the mean length of the main axis of 15 tetrasporelings (with confidence limits) to varying light, temperature, and photoperiodic regimes after $4 \mathrm{~d}$. The solid horizontal line in the lower portion of the graph represents the mean length of the main axis of the inocolum. For rest of legend see Fig. 10

increased dramatically in $16: \overline{8}, L: \overline{\mathrm{D}}$ as compared to corresponding temperatures and light intensities at $8: \overline{16}, L: \bar{D}$. Sporelings continued to survive temperatures as low as $0{ }^{\circ} \mathrm{C}$. Sporelings grown under $16: \overline{8}$, L: $\bar{D}$ grew better than ones under $8: \overline{16}, \mathrm{~L}: \overline{\mathrm{D}}$. All sporelings failed to survive at $35^{\circ} \mathrm{C}$.

\section{Agardhiella subulata}

Growth and/or survival of the tetrasporophytic phase of $A$. subulata proceeded over a broad range of light intensities and temperatures from $10-40 \mu \mathrm{E} \mathrm{m}^{-2} \mathrm{~s}^{-1}$ and $0-30^{\circ} \mathrm{C}$ (Fig. 13). Good growth occurred between $15-30^{\circ} \mathrm{C}$. The tetrasporophytic phase survived 


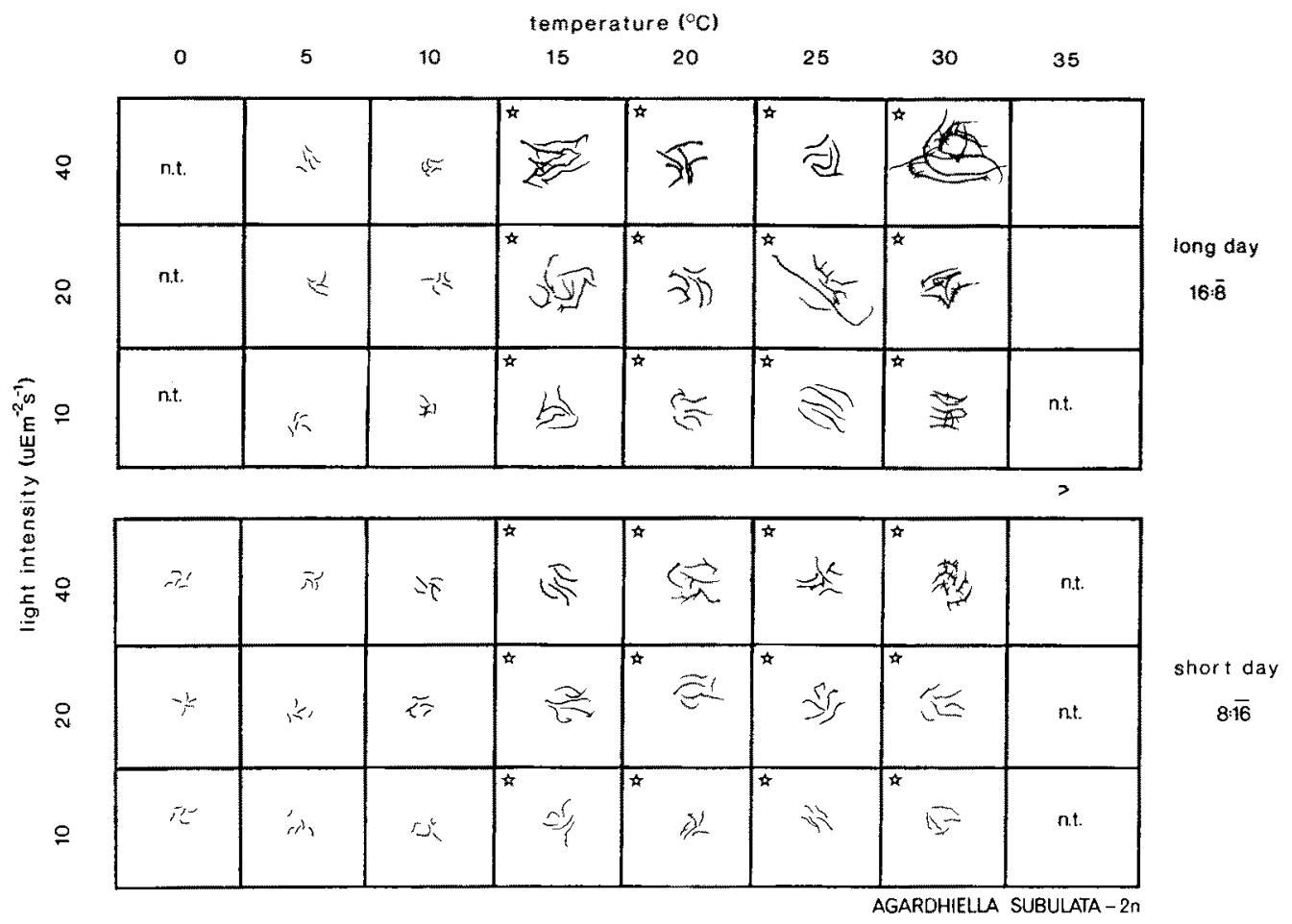

Fig. 13. The growth response of the tetrasporophytic phase of $A$, subulata to varying light, temperature and photoperiodic regimes after $28 \mathrm{~d}$. Experiment was continued for $120 \mathrm{~d}$. Symbols as in Fig. 9. Scale: $1 \mathrm{~mm}=4.5 \mathrm{~mm}$

temperatures of $35^{\circ} \mathrm{C}$ up to 14 days at $40 \mu \mathrm{E} \mathrm{m}^{-2} \mathrm{~s}^{-1}$. The tetrasporophytic phase survived temperatures of $0{ }^{\circ} \mathrm{C}$ up to $90 \mathrm{~d}$ with little or no growth through $10^{\circ} \mathrm{C}$. At $10^{\circ} \mathrm{C}$, plants grown under $16: \overline{8}, \mathrm{~L}: \overline{\mathrm{D}}$ began to bleach out after $28 \mathrm{~d}$, whereas ones grown under $8: \overline{16}$, $\mathrm{L}: \overline{\mathrm{D}}$ did not, thereby indicating chilling damage. Plants grown at $15^{\circ} \mathrm{C}(16: \overline{8}, \mathrm{~L}: \overline{\mathrm{D}})$ attained a much larger size class after 56 days than ones grown at $20-30^{\circ} \mathrm{C}$. As temperature decreased during good growth conditions, i.e. from $30-15^{\circ} \mathrm{C}$, the size of the basal holdfast increased.

The tetrasporophytic phase produced tetrasporangia in $10-40 \mu \mathrm{E} \mathrm{m} \mathrm{m}^{-2} \mathrm{~s}^{-1}$ and at $15-30{ }^{\circ} \mathrm{C}$ (Fig. 13). Plants grown at $20-30^{\circ} \mathrm{C}$ matured faster (28 d) than ones growing at $15^{\circ} \mathrm{C}(90 \mathrm{~d})$. There was no difference in the rate of maturation of plants grown under $16: \overline{8}, L: \bar{D}$ versus $8: \overline{16}, L: \bar{D}$ for corresponding temperatures and light intensities.

\section{Amphiatlantic tropical-to-warm temperate group}

\section{Solieria tenera}

Growth and/or survival of $S$. tenera proceeded over a broad range of light intensities and temperatures from $10-40 \mu \mathrm{E} \mathrm{m}^{-2} \mathrm{~s}^{-1}$ and $0-35^{\circ} \mathrm{C}$ (Fig. 14). Good growth occurred between $15-30^{\circ} \mathrm{C}$. At $25^{\circ} \mathrm{C}$ and $40 \mu \mathrm{E} \mathrm{m} \mathrm{m}^{-2} \mathrm{~s}^{-1}$ plants under long day conditions were highly branched and grew less than corresponding ones at short day conditions. Long 


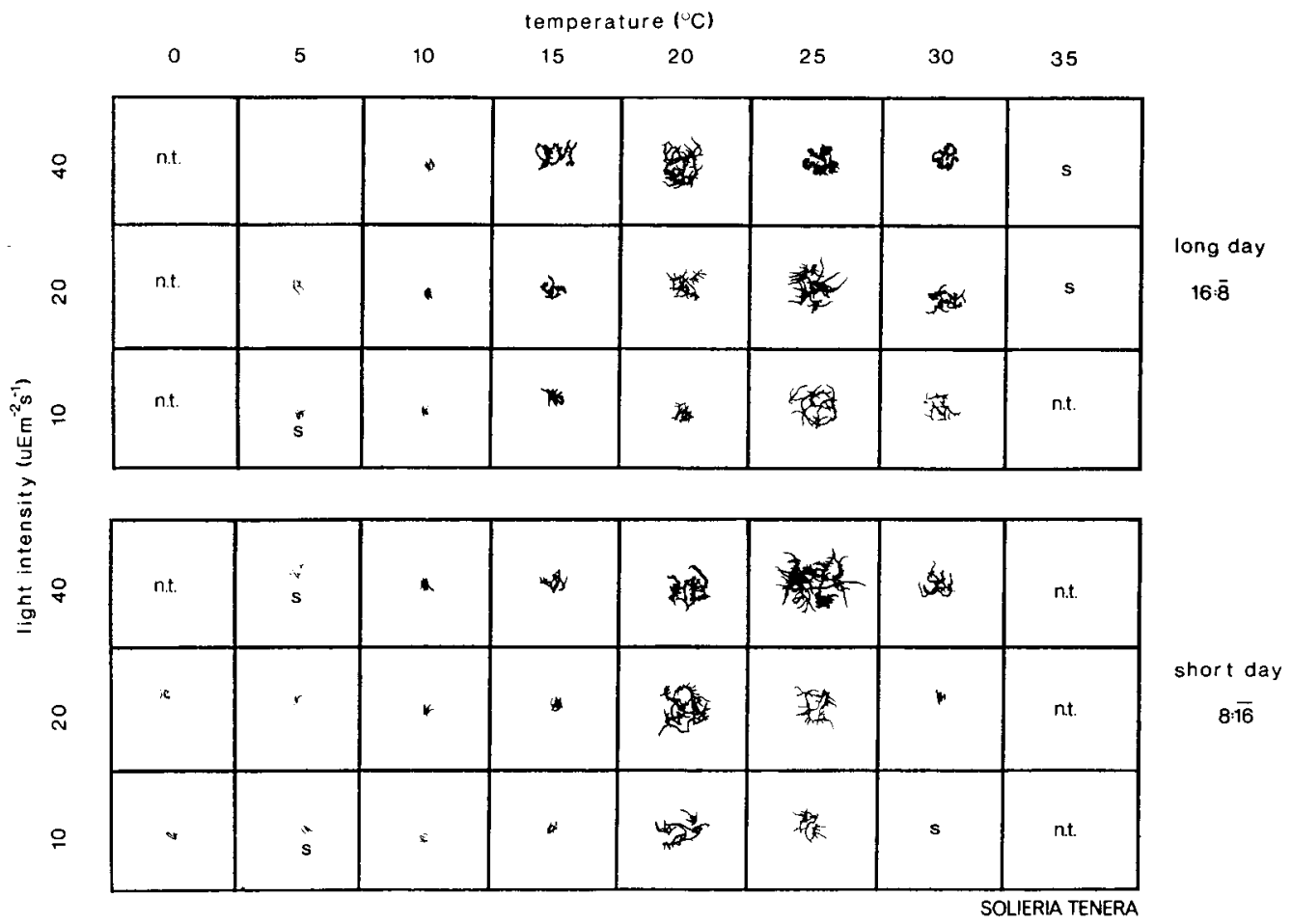

Fig. 14. The growth response of $S$. tenera to varying light, temperature and photoperiodic regimes after 71d. Experiment was continued for 120d. Symbols as in Fig. 9 . Scale: $1 \mathrm{~mm}=6 \mathrm{~mm}$

day plants survived temperatures of $35^{\circ} \mathrm{C}$ for up to $42 \mathrm{~d}$. Bleaching of the apices occurred after $14 \mathrm{~d}$, however, plants continued to survive usually by dying back to their basal region. If these plants were returned to good growth conditions, even after $42 \mathrm{~d}$, they resumed normal growth. Chilling damage was noted at $5^{\circ} \mathrm{C}, 16: \overline{8}, \mathrm{~L}: \overline{\mathrm{D}}$. The plants also survived temperatures as low as $0{ }^{\circ} \mathrm{C}, 8: \overline{16}, \mathrm{~L}: \overline{\mathrm{D}}$ (up to $42 \mathrm{~d}$ ), provided they were previously acclimated for 2 weeks at temperatures of $10^{\circ}$ and $5{ }^{\circ} \mathrm{C}$ respectively. Plants eventually died at this reduced temperature and did not resume growth after being transferred back to good growth temperatures $(>42 \mathrm{~d})$.

\section{The warm temperate Mediterranean Atlantic group}

\section{Halurus equisetifolius}

Growth and/or survival of the tetrasporophytic phase of $H$. equisetifolius proceeded over a narrow range of temperatures from $10-25^{\circ} \mathrm{C}$ at $20 \mu \mathrm{E} \mathrm{m}^{-2} \mathrm{~s}^{-1}$ (Fig. 15). Adequate growth occurred between $10-20^{\circ} \mathrm{C}$. The tetrasporophytic phase survived temperatures of $25^{\circ} \mathrm{C}$ up to $90 \mathrm{~d}$. Plants grown at $30^{\circ} \mathrm{C}$ survived less than $20 \mathrm{~d}$. Chilling damage of plants was evident at $10^{\circ} \mathrm{C}, 16: \overline{8}, \mathrm{~L}: \overline{\mathrm{D}}$.

The tetrasporophytic phase produced tetrasporangia (Fig. 15) at $10^{\circ} \mathrm{C}(8: \overline{16}, \mathrm{~L}: \overline{\mathrm{D}}$ ) and at $15-20^{\circ} \mathrm{C}(16: \overline{8}, \mathrm{~L}: \overline{\mathrm{D}})$. The plants which were grown at $15^{\circ} \mathrm{C}$ matured after $78 \mathrm{~d}$ and the others after $93 \mathrm{~d}$. 


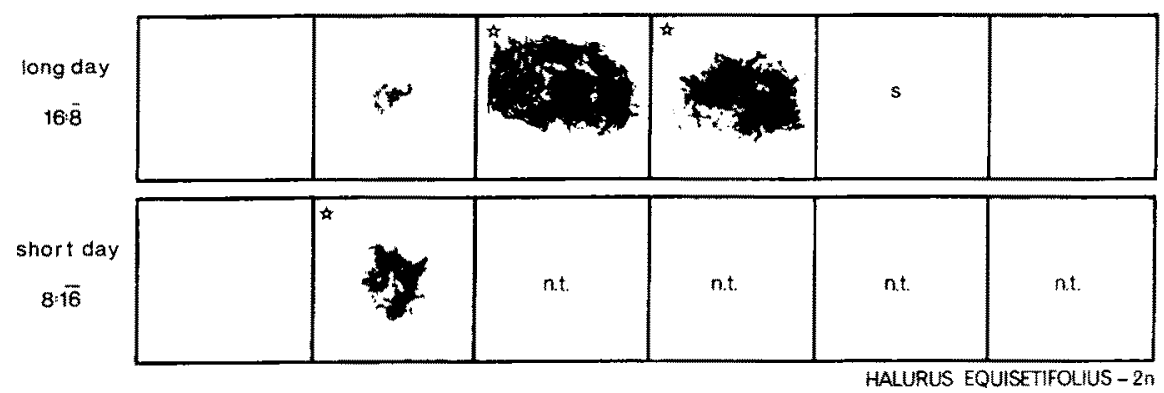

Fig. 15. The growth response of the tetrasporophytic phase of $H$. equisetifolius to varying temperature and photoperiodic regimes at $20 \mu \mathrm{E} \mathrm{m}^{-2} \mathrm{~s}^{-1}$ after $117 \mathrm{~d}$. Experiment was continued for $122 \mathrm{~d}$. Symbols as in Fig. 9. Scale: $1 \mathrm{~mm}=4.3 \mathrm{~mm}$

\section{Callophyllis laciniata}

Growth and/or survival of the tetrasporophytic phase of $C$. laciniata proceeded over a temperature range of $5-25^{\circ} \mathrm{C}$ (Fig. 16). Good growth occurred between $10-20^{\circ} \mathrm{C}$ with $15^{\circ} \mathrm{C}$ being the optimum. The tetrasporophytic phase survived temperatures of $30^{\circ} \mathrm{C}$ less than $20 \mathrm{~d}$ irregardless of the daylength. All plants failed to survive $0^{\circ} \mathrm{C}$ for any appreciable length of time $(<14 \mathrm{~d}$ ). Plants survived longer at a daylength of $8: \overline{16}, \mathrm{~L}: \overline{\mathrm{D}}$ than $16: \overline{8}, \mathrm{~L}: \overline{\mathrm{D}}$ at $5^{\circ} \mathrm{C}$. Chilling damage was observed in these long day plants. The inhibitory effect at $40 \mu \mathrm{E} \mathrm{m} \mathrm{m}^{-2} \mathrm{~s}^{-1}$ and the high temperature of $25^{\circ} \mathrm{C}$ was more pronounced for long day plants versus short day plants, to produce an unexpected interaction.

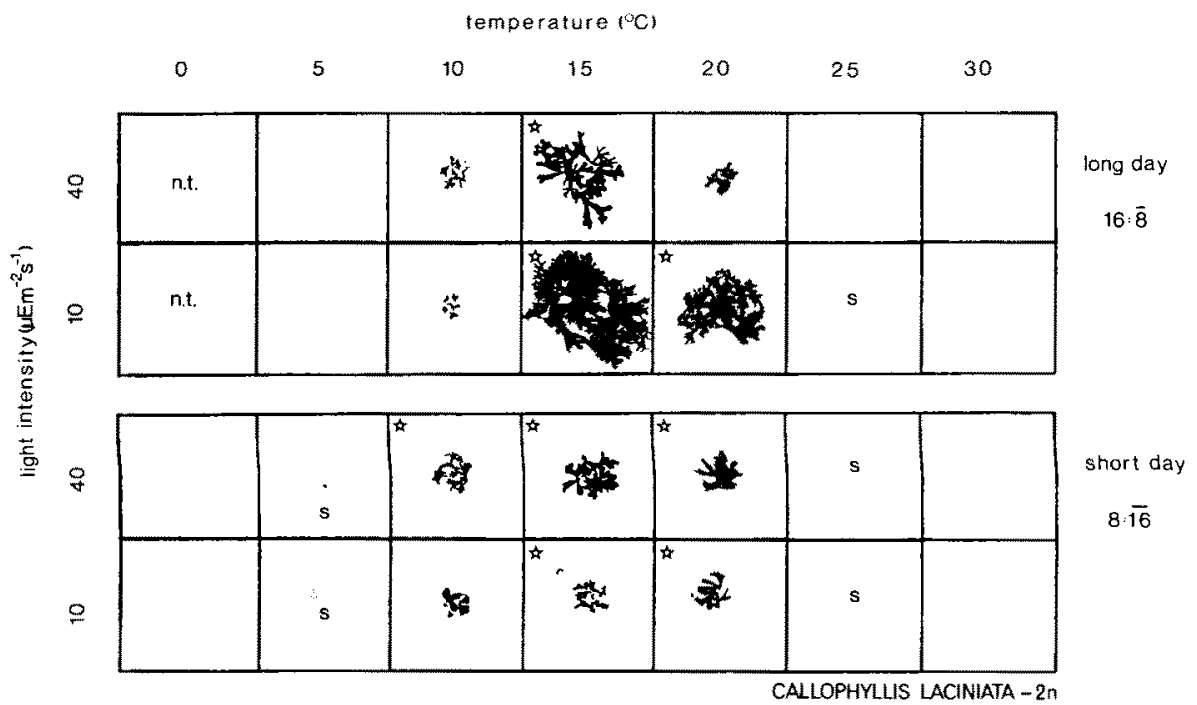

Fig. 16. The growth response of the tetrasporophytic phase of C. laciniata to varying light, temperature and photoperiodic regimes after $117 \mathrm{~d}$. Experiment was continued for $136 \mathrm{~d}$. Symbols as in Fig. 9. Scale: $1 \mathrm{~mm}=4.2 \mathrm{~mm}$ 


\section{Hypoglossum woodwardii}

Growth and/or survival of the tetrasporophytic phase of $H$. woodwardii proceeded over a range of $5-25^{\circ} \mathrm{C}$ (Fig. 17). Good growth occurred between $10-20^{\circ} \mathrm{C}$. The tetrasporophytic phase failed to survive temperatures of $30^{\circ} \mathrm{C}$ for any appreciable length of time $(<24 \mathrm{~d})$. The plants growing at $5^{\circ} \mathrm{C}$, under a daylength of $16: \overline{8}, \mathrm{~L}: \overline{\mathrm{D}}$, failed to survive any longer than $20 \mathrm{~d}$ and chilling damage was observed.

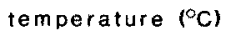

0

5

10

15

20

25

30

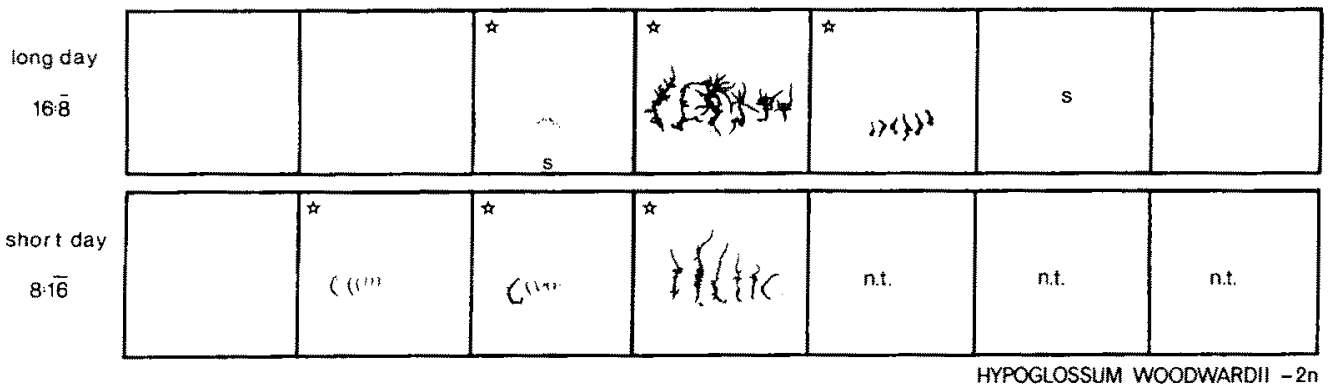

Fig. 17. The growth response of the tetrasporophytic phase of $H$. woodwardii to varying temperature and photoperiodic regimes at $20 \mu \mathrm{E} \mathrm{m}^{-2} \mathrm{~s}^{-1}$ after $117 \mathrm{~d}$. Experiment was continued for $122 \mathrm{~d}$. Symbols as in Fig. 9. Scale: $1 \mathrm{~mm}=6.7 \mathrm{~mm}$

The tetrasporophytic phase produced tetrasporangia at $10-20^{\circ} \mathrm{C}$ (Fig. 17). At $5^{\circ} \mathrm{C}$, tetrasporangia were finally formed after $92 \mathrm{~d}$. In contrast, plants growing at $15-20^{\circ} \mathrm{C}$ produced tetrasporangia after only $41 \mathrm{~d}$. Plants at $5^{\circ} \mathrm{C}$ failed to release their tetraspores even after $122 \mathrm{~d}$.

The growth of tetrasporelings of $H$. woodwardii was maximal at $20^{\circ} \mathrm{C}$ and at $40 \mu \mathrm{E}$ $\mathrm{m}^{-2} \mathrm{~s}^{-1}$. However, the sporelings grew over a range of light, temperature and daylength regimes (Fig. 18). Sporelings survived temperatures as low as $0^{\circ} \mathrm{C}$ and were dead at $30^{\circ} \mathrm{C}$. The inhibitory effects at $40 \mu \mathrm{E} \mathrm{m}^{-2} \mathrm{~s}^{-1}$ and at the high temperature of $25^{\circ} \mathrm{C}$ was more pronounced for long day plants than for short day plants to produce an unexpected interaction.

\section{DISCUSSION}

On the basis of experimental data (Fig. 19, Table 5) and field observations (Figs 1-3) the northern boundary of the investigated species of the Northeast American tropical-totemperate group is a summer growth and/or reproduction one. The northern boundary of $G$. americana is at the $17^{\circ}$ August isotherm and that of $L$. baileyana and $A$. subulata is at the $15^{\circ}$ August isotherm. The latter species, $L$. baileyana and $A$. subulata extend to the southern Gulf of St. Lawrence and, at least north of Cape Cod, they are restricted to protected shallow embayments which warm up in summer to high temperatures, thereby promoting growth and reproduction. As reported by McLachlan \& Bird (1984) for Gracilaria tikvahiae, the period with high temperatures is only long enough to attain reproductive maturity once, suggesting that at least two years are required to complete the life histories in nature. Perhaps the maintenance of $L$. baileyana and $A$. subulata at their northern limit is also by vegetative propagation as in $G$. tikvahiae (Bird et al., 1977). 


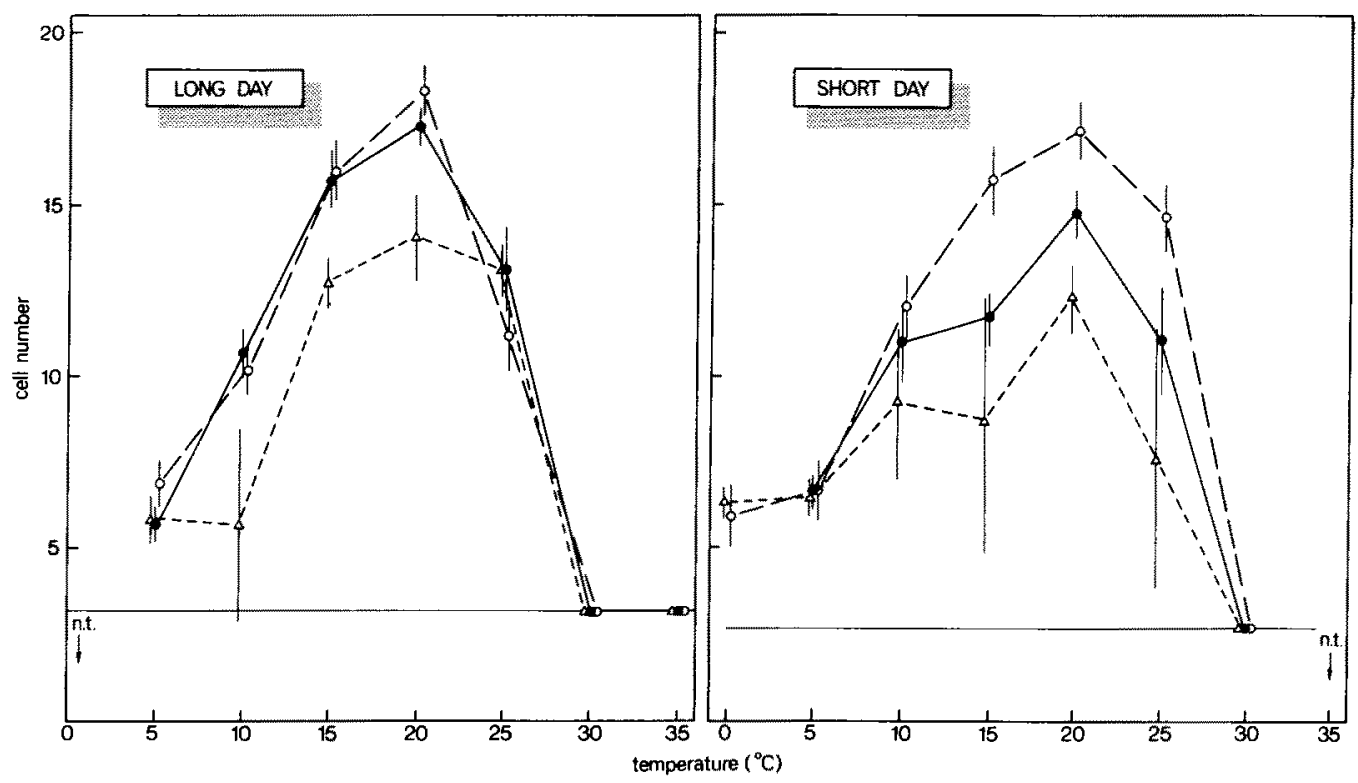

Fig. 18. The growth of $H$. woodwardii expressed as the mean cell number of 15 tetrasporelings (with confidence limits) to varying light, temperature and photoperiodic regimes after $4 \mathrm{~d}$. The solid horizontal line in the lower portion of the graph represents the mean cell number of the inocolum.

For the rest of the legend see Fig. 10
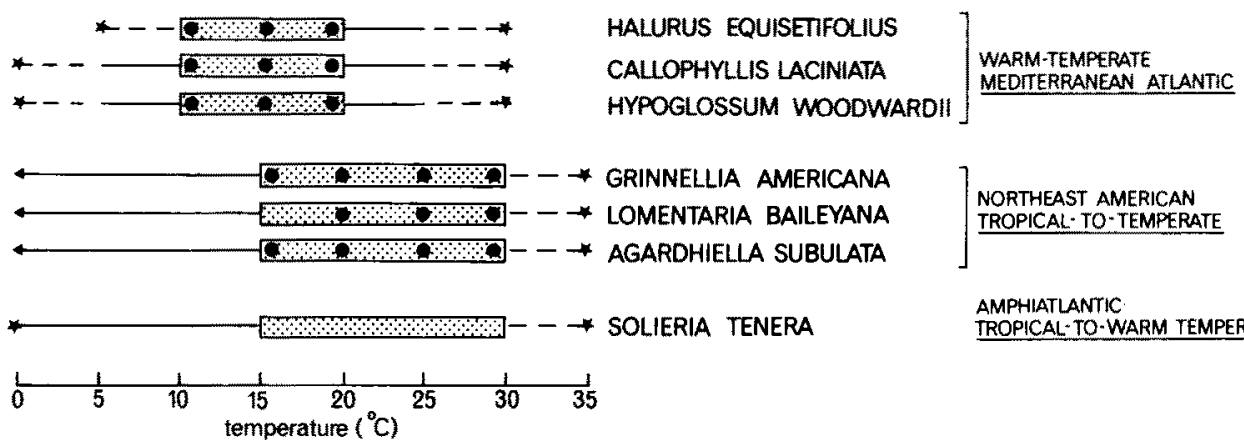

AMPHIATLANTIC TROPICAL-TO-WARM TEMPERATE

Fig. 19. Temperature limits for growth, reproduction and survival of selected benthic marine red algae grouped according to distribition group. The symbols in the bar diagram are defined as $(-)$

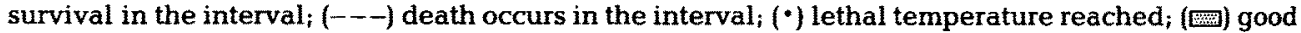
growth in the interval; and $(\bullet)$ reproduction (see text as to the nature of the reproduction)

It takes at least three months at $15^{\circ} \mathrm{C}$ for $A$. subulata tetrasporophytes to reach maturity. For $L$. baileyana, temperatures must be at least $20^{\circ} \mathrm{C}$ to produce fertile tetrasporophytes. Plants growing up to 4 months failed to become fertile at $15^{\circ} \mathrm{C}$. At temperatures $\leqq 15{ }^{\circ} \mathrm{C}$ both algae produce extensive discoid basal systems. Each of the members of the group survived temperatures as low as $0^{\circ} \mathrm{C}$. Evidence of chilling damage (Larcher, 1981) under long day conditions was observed at $5^{\circ} \mathrm{C}$ and $40 \mu \mathrm{E} \mathrm{m}^{-2} \mathrm{~s}^{-1}$. Similar results have been reported by Cambridge et al. (1984) for Cladophora species. 
Table 5. Proposed phytogeographic boundaries in the Northern Hemisphere of selected benthic marine red algae in relation to ocean isotherms as determined experimentally

\begin{tabular}{|c|c|c|c|}
\hline $\begin{array}{l}\text { Phytogeographic } \\
\text { group }\end{array}$ & Species & $\begin{array}{l}\text { Poleward } \\
\text { (lower temperature) } \\
\text { boundary }\end{array}$ & $\begin{array}{l}\text { Equatorward } \\
\text { (upper temperature) } \\
\text { boundary }\end{array}$ \\
\hline \multirow{3}{*}{$\begin{array}{l}\text { Northeast } \\
\text { American } \\
\text { tropical-to- } \\
\text { temperate }\end{array}$} & Grinnellia americana & $\begin{array}{l}17 \text { August, summer } \\
\text { growth/reproduction }\end{array}$ & Tropical margins \\
\hline & Lomentaria baileyana & $\begin{array}{l}15 \text { August, summer } \\
\text { growth/reproduction }\end{array}$ & Tropical margins \\
\hline & Agardhiella subulata & $\begin{array}{l}15 \text { August, summer } \\
\text { growth/reproduction }\end{array}$ & Tropics \\
\hline $\begin{array}{l}\text { Amphiatlantic } \\
\text { tropical-to- } \\
\text { temperate }\end{array}$ & Solieria tenera & $\begin{array}{l}15 \text { August, summer } \\
\text { growth/reproduction } \\
\text { in Europe } \\
\text { ?? in Northeast America }\end{array}$ & Tropics \\
\hline Warm-temperate & Halurus equisetifolius & $\begin{array}{l}7 \text { February, } \\
\text { winter lethal }\end{array}$ & $\begin{array}{l}22 \text { August, } \\
\text { summer lethal }\end{array}$ \\
\hline \multirow[t]{2}{*}{$\begin{array}{l}\text { Mediterranaean } \\
\text { Atlantic }\end{array}$} & Callophyllis laciniata & $\begin{array}{l}4 \text { February, } \\
\text { winter lethal }\end{array}$ & $\begin{array}{l}21 \text { August, } \\
\text { summer lethal }\end{array}$ \\
\hline & $\begin{array}{l}\text { Hypoglossum } \\
\text { woodwardii }\end{array}$ & $\begin{array}{l}6 \text { February, } \\
\text { winter lethal }\end{array}$ & $\begin{array}{l}19 \text { February, winter } \\
\text { growth/reproduction }\end{array}$ \\
\hline
\end{tabular}

The data imply that the restrictive distribution of all of these algae to Northwest America and the Caribbean Sea may be due to the fact that for adequate growth and/or reproduction, water temperatures must exceed the aforementioned critical values. At temperatures $\leqq 15^{\circ} \mathrm{C}$ reproduction and growth is limited, and the amphiatlantic distribution through Iceland would not be permitted.

The ability of $G$. americana, $L$. baileyana and $A$. subulata to grow and reproduce at temperatures of $25-30^{\circ} \mathrm{C}$ permits them to inhabit tropical waters. In this respect these algae show a similar growth strategy to G. tikvahiae (van den Hoek, 1982 b, McLachlan \& Bird, 1984). The lack of published reports on $G$. americana and $L$. baileyana in the Caribbean may be more a function of the size class of these plants. In this study, at higher temperatures, maturation was very rapid at $30^{\circ} \mathrm{C}\left(40 \mu \mathrm{E} \mathrm{m}^{-2} \mathrm{~s}^{-1} ; 16: \overline{8}, \mathrm{~L}: \overline{\mathrm{D}}\right)$; for $G$. americana $24 \mathrm{~d}$ for tetrasporophytes and $34 \mathrm{~d}$ for gametophytes and only $14 \mathrm{~d}$ for $L$. baileyana tetrasporophytes. After maturation there is a gradual disintegration of the upright thalli, thereby making collection of the plants exceedingly difficult in shallow tropical waters.

Similary, Edwards (1969) reported for Ectocarpus siliculosus, and Rietema \& van den Hoek (1981) for macrothalli of Desmotrichum undulatum that high temperatures promote an ephemeral existence towards their southern boundaries. Temperatures above $35^{\circ} \mathrm{C}$ which occur locally in Florida (Earle, 1968) and elsewhere in the tropics would be lethal to $G$. americana, $L$. baileyana and $A$. subulata in the lagoonal habitats they are accustomed to. At $35^{\circ} \mathrm{C}$, whole thalli of each of these plants survive for a limited period of time ( 12 d) whereas the 4 day sporelings of $G$. americana and $L$. baileyana fail to survive; however, such temperatures do not occur in open deep waters (Sverdrup et al., 
1942). It is expected, with more intensive investigations of deep tropical waters, that these algae will be found. As McLachlan \& Bird (1984) suggested, the outflows of the Orinoco and Amazonas rivers may constitute a major ecological barrier for algal species along the South American coast. Of the Northeast American tropical-to-temperate group, only $A$. subulata has successfully hurdled these barriers (Gabrielson \& Hommersand, 1982 a). However, the absence along West African coasts cannot be ascribed to these coasts' ecological unfitness for these species, so here other historical reasons may explain their absence.

Both $G$. americana and $L$. baileyana showed no overall difference in temperature tolerance between the gametophyte and tetrasporophyte generations. This is consistent with the observations of van den Hoek (1982 b) for benthic marine algae with isomorphic generations. McLachlan \& Bird (1984) presented similar observations for Gracilaria species. In contrast, sporelings showed a reduced tolerance to high temperatures $\left(35^{\circ} \mathrm{C}\right)$.

On the basis of experimental data (Fig. 19; Table 5) and field observations the northern boundary of $S$. tenera, a member of the amphiatlantic-tropical-to-warm temperate group, should be set by a $15^{\circ} \mathrm{C}$ August, summer growth and/or reproduction isotherm at least in Europe. Contrary to expectations, the $10^{\circ} \mathrm{C}$ February isotherm which delimits the species distribution to the north both in Europe and America, does not correspond with a lower lethal temperature. We may only speculate what is the controlling factor in Northeast America, South America and Africa, since the Port Isabel, Texas isolate was able to tolerate temperatures down to $0^{\circ} \mathrm{C}$. This isolate only survived $0{ }^{\circ} \mathrm{C}$ when gradually acclimated (at least $14 \mathrm{~d}$ ) at $10^{\circ}$ and $5^{\circ} \mathrm{C}$, respectively. The range of thermal tolerance was extended by $5^{\circ} \mathrm{C}$ (to $0^{\circ} \mathrm{C}$ ). The northernmost point of distribution in North Carolina is an offshore deepwater station bathed by comparatively warm southern water in winter with temperatures hardly lower than $10^{\circ} \mathrm{C}$. More to the north, hard substrates are bathed, at least intermittently, by water that is too cold $\left(\left\langle 5^{\circ}\right)\right.$. The sudden thermal shock (after exposure to freezing) may prohibit rapid formation of any anti-freeze substance (Lüning, 1985), if it were to occur in the eulittoral zone in North Carolina and northwards. The limited southern distribution along the warm water African coast and South American coasts may be functions of poorly known floras. The wide gaps in $S$. tenera's occurrence in Northwest Africa and Europe may be attributed to recent introductions to these regions or possibly, taxonomic confusion with a closely related species, $S$. chordalis (Gabrielson \& Hommersand, $1982 \mathrm{~b}$ ). According to distribution data from Port Isabel and Port Aransas, Texas, U. S. A., (Baca et al., 1979; Edwards \& Kapraun, 1973) and the observations of this study of very slow growth, we may characterize $S$. tenera as a slow growing perennial tropical-to-warm temperate species. Stewart (1984) also reported intrinsically slow growth rates may be characteristic of other tropical perennial red algal genera such as Gelidium and Pterocladia. The Port Isabel isolate was also more tolerant of a high temperature of $35^{\circ} \mathrm{C}$, more so than any member of either the Northeastern American or warm-temperate Mediterrean groups. The only other reported member of this group, Hypnea musciformis (van den Hoek, $1982 \mathrm{~b}$ ), appears to have a similar temperature tolerance.

Dawes et al. (1976) have presented evidence that positive net photosynthetic responses of $H$. musciformis are attained between $4-40^{\circ} \mathrm{C}$, with maxima at $25-32^{\circ} \mathrm{C}$. Biebl (1962) reported that eulittoral marine algae in tropical waters had a temperature tolerance of -2 to $35(40){ }^{\circ} \mathrm{C}$ with an exposure time of only $12 \mathrm{~h}$. However, such short time 
exposures may give a wider tolerance than an exposure time of up to 6 weeks, as was used in this study which simulates conditions in nature more realistically.

The inability of this study to stimulate the development of any reproductive structures under all the combinations of light, temperature and photoperiod, and Farnham's (1980) lack of success in growing tetraspore germlings in culture, suggest that vegetative propagation may be an important mode of reproduction in $S$. tenera. Similar observations have been reported for Polysiphonia subtilissima (Yarish \& Edwards, 1982).

On the basis of experimental data (Fig. 19, Table 5) and field observations (Figs 5-7) the northern boundary of the investigated species of the warm-temperate Mediterranean Atlantic Group is a winter lethal one. The northern boundary of $H$. equisetifolius is at the $7^{\circ}$ isotherm, that of $C$. laciniata is at the $4^{\circ}$ February isotherm and that of $H$. woodwardii is at the $6^{\circ}$ February isotherm.

One note of caution must be made. The preliminary experimental data with tetrasporelings i.e. survival at $0^{\circ} \mathrm{C}$ of $H$. woodwardii does suggest the possibility of a broader geographical distribution than what has been recorded. If additional continuous records can be found for $H$. woodwardii in the North Sea, south of the $12^{\circ}$ August isotherm, then its boundary may be a summer growth and reproduction limit. There is a report of this alga in the Black Sea by Zinova (1967) thereby indicating survival to $0^{\circ} \mathrm{C}$, however, the ability of this population to survive $0^{\circ} \mathrm{C}$ may be enhanced by the low saline environment of the Black Sea. Edwards (1979) also showed a positive temperature/salinity interaction for Callithamnion hookeri (see Druehl, 1981 for a further discussion of salinity/temperature interactions).

The southern boundary of $H$. equisetifolius should be set by a $22^{\circ}$ August summer lethal temperature. Its reported absence from the Canaries, Madeira and the Azores could not be explained; however, recent communications with Prud'homme van Reine (Rijksherbarium, Leiden. The Netherlands) indicate its presence on the Canaries, thereby indicating a wider distribution than the published literature suggests. The absence from Madeira and the Azores may only indicate lack of intensive collection data. The southern boundary of $C$. laciniata may be set by a $21^{\circ} \mathrm{C}$ August summer lethal temperature. The southern boundary of $H$. woodwardii may be set by a $19^{\circ} \mathrm{C}$ February maximum winter temperature for growth and/or reproduction. The inability of the Roscoff isolates tested to withstand temperatures $>25^{\circ} \mathrm{C}$ suggests there may be a different temperature race at the southern boundary, where temperatures are $\geq 27^{\circ} \mathrm{C}$ in summer (i.e. in the eastern Mediterranean). However, the rare occurrence of $H$. woodwardii (1 collection of a plant $1.5 \mathrm{~cm}$ in length at a depth of $27 \mathrm{~m}$ on a rocky bottom, Edelstein, 1964) may preclude this possibility. Another report of its presence in the Black Sea (Zinova, 1967) is also enigmatic, since temperatures there vary from 0 to $29^{\circ} \mathrm{C}$. The possibility exists here too, that there may be a different temperature race in the Black Sea, especially since the marine populations are considered glacial relics (Lüning, 1985).

In summary, the use of mean surface sea water isotherms may be an invaluable tool to generate interesting and testable hypotheses in unravelling the nature of geographical boundaries of benthic red algae. The geographical distributions of the Northeast American tropical-to-temperate group (i. e. G. americana, L. baileyana and A. subulata) correlate with August summer growth and reproduction isotherms at their northern limits of occurrence. On the other hand, the warm-temperate Mediterranean Atlantic group (i.e. $H$. equisetifolius, $C$. laciniata and $H$. woodwardii) is characterized by having 
its northern boundaries at the February winter lethal isotherm. In all cases tested, the Northeast American group survived temperatures as low as $0^{\circ} \mathrm{C}$ whereas the warmtemperate Mediterranean group did not. The Northeast American group was also more tolerant to high temperatures $\left(=30^{\circ} \mathrm{C}\right)$ than the warm-temperate Mediterranean group. The former are able to penetrate the tropics whereas the latter can not. The southern boundaries of the warm-temperate Mediterranean group are heterogenous. $H$. equisetifolius and $C$. laciniata are limited by an August summer lethal isotherm, whereas $H$. woodwardii is limited by a February winter growth and reproduction limit. The boundary limits of the sole representative of the amphiatlantic tropical to temperate group (i.e. S. tenera) are very complex. The populations in Europe are limited by an August summer growth and reproduction isotherm. The boundary limits of the Northeast American, South American und African populations are speculative. In this case, the use of mean surface water isotherm may be limited until additional populations are cultivated in the laboratory and taxonomic uncertainties are resolved. The present day disjunctions which are evident in the published geographical distribution of $S$. tenera may be more a function of post paleoclimates and currents, than present day temperatures (c.f. van den Hoek, 1984).

Acknowledgements. The senior author would like to express his sincere appreciation to: Prof. C. van den Hoek for obtaining financial support from the Netherlands Organization for the Advancement of Pure Research (ZWO) for a sabbatical leave from the University of Connecticut; to ZWO for providing the support and to the staff of the Vakgroep Mariene Biologie of the Rijksuniversiteit Groningen for their helpfulness. Further, the authors are indebted to the following persons and institutions: the Institute of Water Resources of the State of Connecticut; the Director and Dr. J. Cabioch for their hospitality and working facilities at the "Station de Biologie Marine et d'Océanographie" at Roscoff; Prof. F. Magne of the Université Pierre et Marie Curie (Paris VI) who was very helpful in the early stages of this study; Prof. S. van der Spoel, University of Amsterdam, for permission to use a distribution map drawn by him; Dr. M. Kesser and J. Foertch of the Northeast Utilities Service Company for water temperature and unpublished phenological data; Dr. W. Prud'homme van Reine of the Rijksherbarium, Leiden. The Netherlands for unpublished field observations; Dr. R. Hooper, Memorial University of Newfoundland for field observations in Maritime Provinces of Canada; J. Zagers and H. Alberda and the Electron Microscopy Lab in Groningen for photographic assistance; Mr. E. Leeuwinga for preparation of figures; M. E. Top for construction of $0^{\circ} \mathrm{C}$ bath; P. Visscher for photographic assistance; $T$. Joosten for field assistance at Roscoff, France; F. Molenaar for assistance with Agardhiella subulata experiments; M. Aanavi for laboratory assistance; Mrs. K. Cameron and Mrs. J. Spoelstra for typing the manuscript; and particularly to Karen J. Yarish, for moral support and assistance in maintaining all the cultures.

\section{LITERATURE CITED}

Ardré, F, 1970. Contribution à l'étude des algues marines du Portugal. I. La flore. - Port. Acta biol. (Sér. B) 10,1-420.

Ardré, F., 1971. Contribution à l'étude des algues marines du Portugal. - Bull. Cent. Étud. Rech. scient., Biarritz 8, 359-574.

Baca, B. J., Sorensen, L. O. \& Cox, E. R., 1979. Systematic list of seaweeds of South Texas. - Contr. mar. Sci. Univ. Texas 22, 179-192.

Ballisteros i Sagarra, E. \& Martinengo, J. R., 1982. Catálogo de las algas bentónicas (con exclusión de las diatomeas) de la Costa Catalana. - Collnea bot. 13, 723-765.

Biebl, R., 1958. Temperatur- und osmotische Resistenz von Meeresalgen der Bretonischen Küste. Protoplasma 50, 217-242.

Biebl, R., 1962. Temperaturresistenz tropischer Meeresalgen. - Botanica mar. 4, 241-254.

Bird, C. J., Edelstein, T. \& McLachlan, J, 1977. Studies on Gracilaria. Experimental observations on growth and reproduction in Pomquet Harbour, Nova Scotia. - Naturaliste can. 104, 245-255. 
Bodard, M. \& Mollion, J., 1974. La végétation infralittorale de la petite côte Sénégalaise. - Bull. Soc. phycol. Fr. 19, 193-221.

Bolton, J., 1983. Ecoclinal variation in Ectocarpus silicolosus (Phaeophyceae) with respect to temperature growth optima and survival limits. - Mar. Biol. 73, 131-138.

Boudouresque, C. F. \& Perret, M., 1977. Inventaire de la flore marine de Corse (Méditerranée). Cramer, Vaduz, 171 pp. (Bibliotheca Phycologica 25.)

Brauner, J., 1975. Seasonality of epiphytic algae on Zostera marina at Beaufort, North Carolina. Nova Hedwigia 26, 125-133.

Cambridge, M., Breeman, A. M., Oosterwyk, R. van \& Hoek, C. van den, 1984. Temperature responses of some N. Atlantic Cladophora species (Chlorophyceae) in relation to their geographic distribution. - Helgoländer Meeresunters. 38, 349-363.

Chapman, R. L., 1971. The macroscopic marine algae of Sapelo Island and other sites on the Georgia coast. - Bull. Ga Acad. Sci. 29, 77-89.

Cinelli, F., Fresi, E., Mazella, L. \& Ponticelli, M. P., 1979. Deep algal vegetation of the western Mediterranean. - G. Bot. ital. 113, 173-188.

Coleman, D. C. \& Mathieson, A. C., 1974. Investigations of New England marine algae. VI: Distribution of marine algae near Cape Cod, Massachusetts. - Rhodora 76, 537-563.

Conde, F. P., 1984. Catálogo de las algas macrobentonicas marinas de Malaga. - Acta bot. Malacitana 9, 47-78.

Cordeiro-Marino, M., 1978. Rodoficeas bentônicas marinhas do Estado de Santa Catarina. - Rickia 7, 1-243.

Cormaci, M. \& Furnari, G., 1979. Flora algale marina della Sicilia orientale: "Rhodophyceae", "Phaeophyceae" and "Chlorophyceae". - Inf. bot. ital. 11, 221-250.

Cullinane, J. P. \& Whelan, P. M., 1983. Subtidal algal communities on the south coast of Ireland. Cryptogamie 4, 117-125.

Dangeard, P., 1949. Les algues marines de la côte occidentale du Maroc. - Botaniste 34, 89-189.

Dawes, C. J., 1974. Marine algae of the west coast of Florida. Univ. Miami Press, Coral Gables, Fla., $201 \mathrm{pp}$.

Dawes, C. J., Moon, R. E. \& LaClaire II, J. W., 1976. Photosynthetic responses of the red alga, Hypnea musciformis (Wulfen) Lamouroux (Gigartinales). - Bull. mar. Sci. 26, 467-473.

Donze, M., 1968. The algal vegetation of the Rio de Arosa (NW Spain). - Blumea 16, 159-183.

Dring, M. J., 1982. The biology of marine plants. Arnold, London, $199 \mathrm{pp}$.

Druehl, L. D., 1981. Geographical distribution. In: The biology of seaweeds. Ed. by C. S. Lobban \& M. J. Wynne. Univ. of California Press, Berkeley, 306-325.

Earle, S. A., 1968. Preliminary checklist of the marine plants in the vicinity of the Mote Marine Laboratory, Sarasota, Florida, 10 pp. (Mimeo)

Edelstein, T., 1964. On the sublittoral algae of the Haifa Bay area. - Vie Milieu 15, 177-212.

Edelstein. T., McLachlan, J. \& Craigie, J., 1967. Investigations of the marine algae of Nova Scotia. II. Species of Rhodophyceae new or rare to Nova Scotia. - Can. J. Bot. 45, 193-202.

Edwards, P., 1969. Field and cultural studies on the seasonal periodicity of growth and reproduction of selected Texas benthic marine algae. - Contr. mar. Sci. Univ. Texas 14, 59-114.

Edwards, P., 1970. Field and cultural observations on the growth and reproduction of Polysiphonia denudata from Texas. - Br. phycol. J. 5, 145-153.

Edwards, P., 1975. An assessment of possible pollution effects over a century on the benthic algae of Co. Durham, England. - Bot. J. Linn. Soc. 70, 269-305.

Edwards, P., 1979. A cultural assessment of the distribution of Callithamnion hookeri (Dillw.) S. F. Gray (Rhodophyta, Ceramiales) in nature. - Phycologia 18, 251-263.

Edwards, P. \& Kapraun, D. F., 1973. Benthic marine algal ecology in the Port Aransas, Texas area. Contr. mar. Sci. Univ. Texas 17, 15-52.

Edwards, P., Bird, E., Cotgreave, B., Cossins, A., Crompton, K., Fowler, W., Herdson, D. \& Hudson, J., 1975. Marine phytobenthos of the Castellabate (Cilento) Natural Park, Salerno, Italy, Phytocoenologia 1, 403-426.

Egan, B., 1983. Notes on the marine algae of Ballycotton Bay, Co. Cork. - Ir. Nat. J. 21, 156-160.

Farnham, W. F., 1980. Studies on aliens in the marine flora of southern England. In: The shore environment. Ed. by J. H. Price, D. E. G. Irvine \& W. F. Farnham. Acad. Press, London, 2, 875-914. 
Feldmann, J., 1931. Contribution à la flore algologique marine de l'Algérie: Les algues de Cherchell. - Bull. Soc. Hist. Nat. Afr. N. 22, 179-254.

Feldmann, J., 1937. Recherches sur la végétation marine de la Méditerranée. La Côte des Albères.Revue algol. 10, 1-339.

Feldmann, J, 1939. Les algues marines de la Côte des Albères IV. - Revue algol. 11, 247-330.

Feldmann, J., 1941. Les algues marine de la Côte des Albères IV. - Revue algol. 12, 77-100.

Feldmann, J., 1942. Les algues marines de la Côte des Albères IV. - Trav. algol. 1, 29-118.

Feldmann, J., 1943. Contribution à l'étude de la flore marine de profondeur sur les côtes d'Algérie. Bull. Soc. Hist. nat. Afr. N. 34, 150-167.

Feldmann, J., 1951. La flore marine de l'Afrique du nord. - C. R. somm. Soc. Biogéogr. 243, 103-108.

Feldmann, J., 1954. Inventaire de la flore marine de Roscoff. - Trav. Stn. biol. Roscoff 6, 1-152.

Gabrielson, P. W. \& Hommersand, M. H., 1982a. The morphology of Agardhiella subulata representing the Agardhielleae, a new tribe in the Solieriaceae (Gigartinales, Rhodophyta). - J. Phycol. 18, 46-58.

Gabrielson, P. W. \& Hommersand, M. H., 1982b. The Atlantic species of Solieria: their morphology, distribution and affinities. - J. Phycol. 18, 31-45.

Gayral, P., 1958. Algues de la côte Atlantique Marocaine. La nature au Maroc. II. Société des sciences naturelles et physiques du Maroc, Rabat, 523 pp.

Gerloff, J. \& Geissler, U., 1974. Eine revidierte Liste der Meeresalgen Griechenlands. - Nova Hedwigia 22, 721-793.

Giaccone, G., 1969. Raccolte di fitobenthos sulla banchina continentale Italiana. - G. Bot. ital. 103, 485-514.

Giaccone, G., 1972. Struttura, ecologia e corologia dei popolamenti a Laminarie dello Stretto di Messina e del Mare di Alboran. - Memorie Biol. mar. Oceanogr. 2, 37-59.

Giaccone, G., 1978. Revisione della flora marina del Mare Adriatico. - Annuar. Parco mar. Miramare, Staz. Control., Trieste (Suppl.) 1977, 1-118.

Giaccone, G. \& Longo, L. R., 1976. Revisione della flora dello Stretto di Messina (note stroriche, bionomiche e corologiche). - Memorie Biol. mar. Oceanogr. 6, 69-122.

Gil-Rodriguez, M. C. \& Afonso-Carrillo, J., 1980. Catálogo de las algas marinas bentonicas (Cyanophyta, Chlorophyta, Phaeophyta y Rhodophyta) para El Archipielago Canario. Aula de Cultura de Tenerife, Santa Cruz, 47 pp.

Guiry, M. D., 1978. A consensus and bibliography of Irish seaweeds. Cramer, Vaduz, $278 \mathrm{pp}$. (Bibliotheca Phycologia 44).

Hamm, D. \& Humm, H. J., 1976. Benthic algae of the Anclote estuary. II. Bottom dwelling species. Fla Scient. 39, 209-229.

Hartog, C. den, 1959. The epilithic algal communities occurring along the coast of the Netherlands. - Wentia 1, 1-241.

Hoek, C. van den, 1975. Phytogeographic provinces along the coast of the northern Atlantic Ocean. - Phycologia 14, 317-330.

Hoek, C. van den, 1982a. Phytogeographic distribution groups of benthic marine algae in the North Atlantic Ocean. A review of experimental evidence from life history studies. - Helgoländer Meeresunters. 35, 153-214.

Hoek, C. van den, 1982b. The distribution of benthic marine algae in relation to the temperature regulation of their life histories. - Biol. J. Linn. Soc. 18, 81-144.

Hoek, C. van den, 1984. World-wide latitudinal and longitudinal seaweed distribution patterns and their possible causes, as illustrated by the distribution of rhodophytan genera. - Helgoländer Meeresunters. 38, 227-257.

Hoek, C. van den \& Donze, M., 1966. The algal vegetation of the rocky Côte Basque (SW France).Bull. Cent. Etud. Rech. scient., Biarritz 6, 259-319.

Hoek, C. van den \& Donze M, 1967. Algal phytogeography of the European Atlantic coasts. Blumea $15,63-89$.

Humm, H. J., 1964. Epiphytes of the sea grass, Thalassia testudinum, in Florida. - Bull. mar. Sci. Gulf Caribb. 15, 306-341.

Humm, H. J., 1979. The marine algae of Virginia. Univ. Press, Charlottesville, Virginia, 263 pp.

Irvine, D. E. G., 1982. Seaweeds of the Faroes. I. The flora. - Bull. Br. Mus. nat. Hist. (Bot.) 10, 109-131. 
Irvine, L. M., 1983. Seaweeds of the British Islands. Vol. 1. Rhodophyta. Part. 2A. Cryptonemiales (sensu stricto), Palmariales, Rhodymeniales. British Museum (Natural History), London, $115 \mathrm{pp}$.

Juett, L., Miller, C. J., Moure, S. J. \& Ford, E. S., 1976. Summer marine algae at Vero Beach, Florida. - Fla Scient.' 39, 76-80.

Kain, J. M., 1960. Direct observations on some Manx sublittoral algae. - J. mar. biol. Ass. U. K. 39, $609-630$.

Kain, J. M., 1982. The reproductive phenology of nine species of Rhodophyta in the subtidal region of the Isle of Man. - Br. phycol. J. 17, 321-331.

Kapraun, D. F., 1977a. Studies on growth and reproduction of Antithamnion cruciatum (Rhodophyta, Ceramiales) in North Carolina. - Norw. J. Bot. 24, 264-274.

Kapraun, D. F., 1977b. The genus Polysiphonia in North Carolina, USA. - Botanica mar. 20, 313-331.

Kapraun, D. F, 1978. Field and cultural studies on selected North Carolina Polysiphonia species. Botanica mar. 21, 143-153.

Kapraun, D. F., 1979. Comparative studies of Polysiphonia urceolata (Lightf.) Grev. (Rhodophyta, Ceramiales) in the North Atlantic. - Norw. J. Bot. 26, 269-276.

Kapraun, D. F., 1980. Floristic affinities of North Carolina inshore benthic marine algae. - Phycologia 19, 245-252.

Kapraun, D. F. \& Zechman, F. W., 1982. Seasonality and vertical zonation of benthic marine algae on a North Carolina coastal jetty. - Bull. mar. Sci. 32, 702-714.

Laboratoire de I'I.S.T.P.M. de Roscoff, 1976. Température et salinité de l'eau de mer au large de Roscoff au cours des années 1959 à 1970. - Trav. St. biol. Roscoff 23, 31-39.

Larcher, W., 1981. Effects of low temperature stress and frost injury on plant productivity. In: Physiological processes limiting plant productivity. Ed. by C. B. Johnson. Butterworth Press, Kent, 253-267.

Lawson, G. W. \& John, D. M., 1977. The marine flora of the Cap Blanc Penninsula: its distribution and affinities. - Bot. J. Linn. Soc. 75, 99-118.

Lawson, G. W. \& John, D. M., 1982. The marine algae and coastal environment of tropical West Africa. - Nova Hedwigia Beih. 70, 1-455.

Levring. T., 1974. The marine algae of the Archipelago of Madeira. - Bolm. Mus. munic. Funchal 28, 5-111.

Lüning, K., 1984. Temperature tolerance and biogeography of seaweeds: the marine algal flora of Helgoland, North Sea, as an example. - Helgoländer Meeresunters. 38, 305-317.

Lüning, K., 1985. Meeresbotanik. Thieme, Stuttgart (in press).

Maggs, C. A., Freamhainn, M. T. \& Guiry, M. D., 1983. A study of the marine algae of subtidal cliffs in Lough Hyne (INE), Co Cork. - Proc. R. Ir. Acad. 83 B, 251-266,

Mathieson, A. C., 1979. Vertical distribution and longevity of subtidal seaweeds in northern New England, U.S.A. - Botanica mar. 30, 511-520.

Mathieson, A. C. \& Fuller, S. W., 1969. A preliminary investigation of the benthonic marine algae of the Chesapeake Bay Region. - Rhodora 71,524-534.

Mathieson, A. C. \& Dawes, C. J., 1975. Seasonal studies of Florida sublittoral marine algae. - Bull. mar. Sci. 25, 46-65.

McLachlan, J. \& Bird, C. J., 1984. Geographical and experimental assessment of the distribution of species of Gracilaria Grev. (Rhodophyta, Gigartinales) in relation to temperature. - Helgoländer Meeresunters. 38, 319-334.

Meñez, E. G. \& Mathieson, A. C., 1981. The marine algae of Tunisia. - Smithson. Contr. mar. Sci. 10, $1-59$.

Meunier, A. 1956. Etude de la végétation algale du Cap St. Martin (Biarritz). Thèse, Bordeaux, $178 \mathrm{pp}$.

Navarro, F. de P. \& Uriarte, B. L., 1945. Catálogo de la flora del mare de Baleares (con exclusion de las Diatomeas). - Boln. Inst. esp. Oceanogr. (Notas y Resumenes. Ser. 2) 124, 161-298.

Newton, L., 1931. A handbook of the British seaweeds. British Museum, London, $487 \mathrm{pp}$.

Nizamuddin, M., West, J. A. \& Meñez, E. G., 1979. A list of marine algae from Libya. - Botanica mar. $22,465-476$.

Norton, T. A., 1970. The marine algae of County Wexford, Ireland. - Br. phycol. J. 5, 257-266.

Norton, T. A., 1976. The marine algae of the eastern border counties of Scotland. - Br. phycol. J. 11, $19-27$. 
Norton, T. A. \& Powell, H. T., 1979. Seaweeds on rocky shores of the Outer Hebrides. - Proc. R. Soc. Edinb. 77 B, 141-153.

Oliveira Filho, E. C. de, 1977. Algas marinhas bentônicas do Brasil. Thesis, Universidade de Sao Paulo, $407 \mathrm{pp}$.

Orris, P. K. \& Taylor, J. E., 1973. A floristic and ecological survey. The benthic macroalgae of Rehoboth Bay, Delaware. - Botanica mar. 16, 180-192.

Parke, M. \& Dixon, P. S., 1976. Check-list of British marine algae third revision. - J. mar, biol. Ass. U.K. 56, 527-594.

Perez-Cirera, J. L. 1975a. Catálogo floristico de las algas bentonicas de la Ria de Cedeira, NO de España. - An.Inst. bot. A. J. Cavanilles 32, 53-74.

Perez-Cirera, J. L., 1975b. Catálogo floristico de las algas bentonicas de la Ria de Corme y Lage, NO de España. - An. Inst. bot. A. J. Canavilles 32, 5-87.

Provasoli, L., 1968. Media and prospects for cultivation of marine algae. In: Cultures and collections of algae (Proc. U.S.-Japan Conference Hakone, Sept. 1966). Ed. by A. Watanabe \& A. Hattori. Jap. Soc. Plant Physiol., 63-75.

Rhodes, R. G., 1970. Seasonal occurrence of marine algae on an oyster reef in Burton's Bay, Virginia. - Chesapeake Sci. 11, 61-71.

Rietema, H. \& Hoek, C. van den, 1981. The life history of Desmotrichum undulatum (J. Ag.) Reinke, (Phaeophyceae) and its regulation by temperature and light conditions. - Mar. Ecol. Prog. Ser. 4, 321-335.

Rueness, J., 1977. Norsk Algeflora. Universitetsforlaget, Oslo, $266 \mathrm{pp}$.

Russell, G., 1961-62. Observations on the marine algae of the Isle of May. - Trans. bot. Soc. Edinb. 39, 271-289.

Russell, G., 1968. List of marine algae from the Isles of Scilly. - Br. phycol. Bull. 3, 579-584.

Schmidt, O.C., 1931. Die marine Vegetation der Azoren in ihren Grundzügen dargestellt. Bibliotheca bot. 102, 1-116.

Schneider, C. W., Suyemoto, M. M. \& Yarish, C., 1979. An annotated checklist of Connecticut seaweeds. - Bull. geol. nat. Hist. Surv., Conn. 108, 1-20.

Searles, R. B. \& Schneider, C. W., 1978. A checklist and bibliography of North Carolina seaweeds. Botanica mar. 21, 99-108.

Sears, J.R. \& Wilce, R. T., 1975. Sublittoral, benthic marine algae of Southern Cape Cod and adjacent islands: Seasonal periodicity, associations, diversity, and floristic composition. - Ecol. Monogr. 45, 337-365.

Seoane-Camba, J. A., 1960. Nota sobre algunas especies de algas de la costa occidental africana (sur de Cabo Blanco). - Investigación pesq. 16, 91-103.

Seoane-Camba, J. A., 1965. Estudies sobre las algas bentonicas en la costa sur de la Peninsula Ibérica (litoral de Cadiz). - Investigación pesq. 29, 3-216.

Setchell, W. A., 1915. The law of temperature connected with the distribution of the marine algae. Ann. Mo. bot. Gdn 2, 287-305.

Setchell, W. A., 1920. The temperature interval in the geographical distribution of marine algae. Science, N. Y. 53, 187-190.

South, G. R. \& Cardinal, A., 1970. The marine algae of eastern Canada. - Can. J. Bot. 48, $2077-2095$.

Stewart, J. G., 1984. Vegetative growth rates of Pterocladia capillacea (Gelidiaceae, Rhodophyta). Botanica mar. 27, 85-94.

Sverdrup, H. U., Johnson, M. W. \& Fleming, R. H., 1942. The Oceans. Prentice Hall, Englewood Cliffs, N. J., 1060 pp.

Taylor, W. R., 1957. Marine algae of the Northeastern coast of North America. Univ. of Michigan Press, Ann Arbor, $509 \mathrm{pp}$.

Taylor, W. R, 1960. Marine algae of the eastern tropical and substropical coasts of the Americas. Univ. of Michigan Press, Ann Arbor, 870 pp.

Tittley, I., Irvine, D. E. G. \& Jephson, N. A., 1976. The infralittoral marine algae of Sullan Voe, Shetland. - Trans. bot. Soc. Edinb. 42, 397-419.

Yarish, C. \& Edwards, P., 1982. A field and cultural investigation of the horizontal and seasonal distribution of estuarine red algae of New Jersey. - Phycologia 21, 112-124.

Zaneveld, J. S., 1972. The benthic marine algae of Delaware, U.S.A. - Chesapeake Sci. 13, 120-138.

Zinova, A. D., 1967. Opredel'itel' zel'enych, burych i krasnych vodoroslej juz̃nych mor'ej SSSR. Izd. "Nauka", Leningrad, $398 \mathrm{pp}$. 